\title{
Working
}

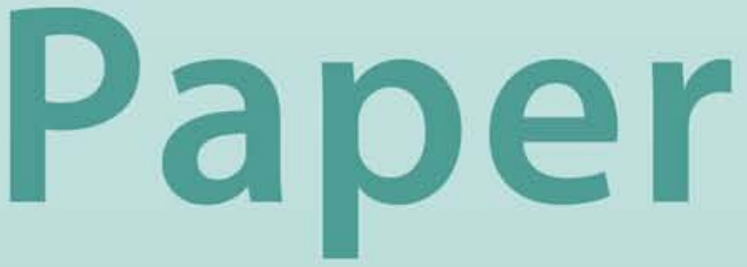


China: Strengthening Monetary Policy Implementation

Bernard J. Laurens and Rodolfo Maino 


\title{
IMF Working Paper
}

Monetary and Capital Markets Department

\section{China: Strengthening Monetary Policy Implementation}

\author{
Prepared by Bernard J. Laurens and Rodolfo Maino ${ }^{1}$ \\ Authorized for distribution by Peter Stella
}

January 2007

\begin{abstract}
This Working Paper should not be reported as representing the views of the IMF. The views expressed in this Working Paper are those of the author(s) and do not necessarily represent those of the IMF or IMF policy. Working Papers describe research in progress by the author(s) and are published to elicit comments and to further debate.

The People’s Bank of China (PBC) has made great strides in modernizing its monetary policy frameworks but their effectiveness will diminish as the sophistication of the economy increases. Empirical evidence supports maintaining a reference to money in China's monetary strategy and enhancing the role of interest rates in its conduct. We advocate adoption of an eclectic strategy involving the monitoring of several indicators, and of a short-term interest rate as the operational target. The PBC should be granted discretion to change its policy rate, and there are no technical obstacles for such a move to occur in the near future.
\end{abstract}

JEL Classification: E42, E52, E58

Keywords: Monetary policy, money demand, multipliers, monetary policy instruments.

\section{Authors’ E-Mail Address:blaurens@imf.org ; rmaino@imf.org}

\footnotetext{
${ }^{1}$ A preliminary version of the paper was prepared for a course at the Joint IMF-China Training Center on “Determining the Intermediate Target for Monetary Policy: Practical Issues,” Dalian (China), June 19-22, 2006. The authors are grateful, without implication, to Steven Barnett, Ulrich Bindseil, Alexandre Chailloux, Dong Dibin, Stephen Green, Sun Guofeng, Turgut Kisinbay, Lamin Leigh, Klaus Masuch, Anna Nordstrom, Richard Popdiera, Eswar Prasad, Mark Stone and Barry Topf for their comments, as well as participants in a seminar held at the People’s Bank of China on December 15, 2006 to discuss a draft version of the paper.
} 
I. Introduction and Summary

II. China’s Current Macroeconomic and Financial Sector Attributes ................................... $\underline{5}$

A. Macroeconomic Attributes........................................................................

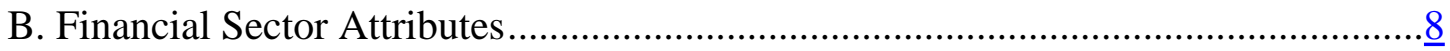

III. Current Frameworks for Monetary Policy ........................................................... 10

A. China's Experience with Monetary Targeting .................................................

B. China's Experience with Monetary Policy Implementation .................................11

C. Obstacles to the Effectiveness of Interest Rates as an Operating Target .................18

IV. Money as an Intermediate Target: Empirical Evidence for China ................................20

A. Survey of Previous Research .................................................................. $\frac{20}{21}$

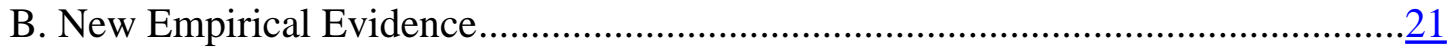

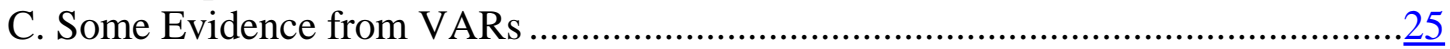

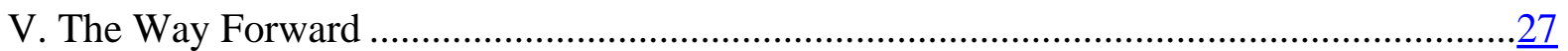

A. General Considerations ..........................................................................

B. Strengthening China's Strategic Framework ..................................................

C. Strengthening China’s Operational Framework.................................................35

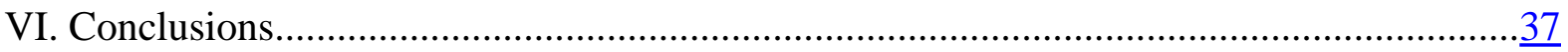

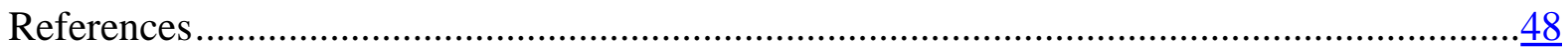

Tables

1. China: Targeted and Actual Values for Monetary Aggregates, 1994-2004................11

2. China: Required and Excess Reserves, 2000-2005 ..............................................19

3. China: Persistence and Variability of Inflation, 1994-2004 (quarterly).....................24

4. Stylized Structure of Interest Rates.....................................................................

Figures

1. China: Selected Macroeconomic Indicators ........................................................ 7

2. China: Structure of Interest Rates, 2000-2006........................................................14

3. China: Inflation and Money Growth, 1994-2006 ....................................................22

4. China: Inflation and Money Growth (Kernel Graph) .............................................23

5. China: Money Multiplier ….........................................................................23

6. China: Responses of Prices and GDP to one SD Money Innovation .........................25

7. China: Response of GDP to one SD Interest Rate Innovation..................................26

8. Stylized Representation of the Channels of Transmission ........................................29 


\section{Boxes}

1. China: Main Monetary Policy Instruments......................................................

2. Initial Conditions for Inflation Targeting …..........................................................

3. Monitoring Mechanisms of Banks’ Margins: Country Examples ................................. $\underline{36}$

4. Cross-Country Experiences with Dealing with a Liquidity Surplus..............................37

\section{Appendixes}

I. Why the PBC Should Rely on Market-Based Monetary Policy ................................. 40

II. Monetary Policy with Open Capital Account and Large Capital Inflows ....................41

III. Modeling Money Demand in China ...............................................................

IV. Monitoring Financial and Monetary Indicators as Intermediate Targets................... 45

V. The Role of Money in the ECB Monetary Strategy …........................................46 


\section{INTRODUCTION AND SUMMARY}

Since the People's Bank of China (PBC) started to adopt the functions of a central bank back in 1984, it has moved gradually to a monetary strategy anchored on intermediate monetary targets. Currently, it announces targets for the growth of a broad monetary aggregate (M2) in line with the policy objectives of maintaining the stability of the value of the currency and thereby promoting growth. The PBC has also developed a set of monetary policy instruments similar to those used by the most advanced central banks, including reserve requirements and open market operations (OMOs), but it also uses administrative measures.

However, some thirteen years after the November 1993 milestone decision of the Third Plenum, the liberalization of interest rates is not yet completed. ${ }^{2}$ The gradual approach adopted in liberalizing the financial sector has also led to financial market segmentation, which adds additional friction to the dynamics of interest rates. The monetary transmission mechanism is affected by remaining weaknesses in the banking system, and the policy interest rate is not pivotal as a transmission channel of monetary impulses. As a corollary to the yet limited reliance on market forces for financial resources allocation, the monetary authorities still rely considerably on administrative controls, and the balance between those and market-based monetary instruments continues to be in favor of the former. In particular, the PBC relies on reserve requirements to a greater extent than other major central banks. It also relies on moral suasion to provide guidance for credit growth and its sectoral allocation-a practice no longer used by major central banks. Finally, most (if not all) policy changes at the $\mathrm{PBC}$, in particular changes to the $\mathrm{PBC}$ interest rates, have to be validated by the State Council.

The effectiveness of the current approach to policymaking is likely to diminish as the sophistication of China's economy increases. As financial innovation and opening to the outside world accelerates, the reasons that caused developed countries and emerging economies to downplay the role of money in monetary policy making have started to surface in China. Furthermore, the effectiveness of the market-based approach to monetary policy that was initiated back in 1998, when quantitative credit controls were eliminated, is held back due to several obstacles. First, the PBC is still burdened with a multiplicity of policy objectives and it does not enjoy full discretion to set its policy interest rates. Second, banks' excess reserves and the segmentation of the money market hamper the interest rate channel of transmission of monetary policy.

\footnotetext{
${ }^{2}$ The Third Plenary Session of the 14th Central Committee of the Communist Party of China Third Plenum laid down, for the first time, the goals of establishing a socialist market economy by the end of the century, thereby allowing the market to play a decisive role in resource allocation (see Mehran, Laurens and Quintyn, 1996). However, commercial banks are subject to a device to protect their intermediation margins (deposit rates are subject to a ceiling and lending rates to a floor).।, and rural credit cooperatives are still subject to an interest rate ceiling on loans.
} 
Against this background, greater reliance on market forces would increase economic efficiency and growth. Subjecting commercial banks, which continue to dominate the financial sector, to price incentives would enhance the efficient allocation of their large deposit base. China's money market, which is the cornerstone of a competitive and efficient system of market-based intermediation, would benefit from a more market-based implementation of monetary policy. In turn, a more efficient money market will help strengthen the interest rate monetary policy transmission channel, and develop China's equity and bond markets, which are among the smallest in the world on a relative basis.

With this in mind, this paper discusses practical and operational issues to strengthen China's monetary policy framework. The remainder of the paper is organized as follows: Section II discusses China's current macroeconomic and financial sector attributes that are relevant for the choice of intermediate and operating targets for monetary policy. Section III describes the current operational framework for monetary policy. Section IV present results of empirical research on the reliability of money as an intermediate target. Section $\mathrm{V}$ advances some of the main elements to strengthen monetary policy frameworks for the medium and long run, and discusses policy measures to address some of the concerns of the authorities regarding the potential disruptions that may result from a shift to fully-fledged monetary policy. Sections VI concludes, and Appendix I summarize in four arguments why a move to fullyfledged market-based monetary policy has now become the most pressing issue for the Chinese monetary authorities.

\section{China’s Current Macroeconomic and Financial Sector Attributes}

The literature has emphasized the linkages between the macroeconomic attributes of countries and the choice of a monetary framework, but the implications of financial sector attributes on that choice have been somewhat overlooked. The literature with regard to macroeconomic attributes can be summarized by referring to the "impossible trinity" hypothesis first proposed in the Mundell-Fleming model. It represents the impossibility to maintain a fixed

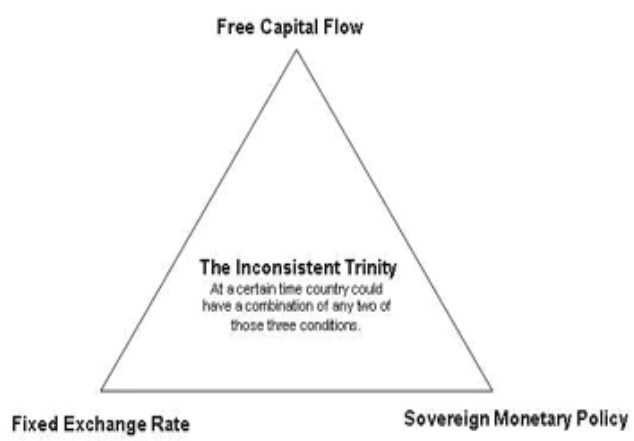
exchange rate, free capital flows, and to have an independent monetary policy (see Figure). The feasible regions are any combinations of two of the above-mentioned conditions.

As to financial sector attributes, there is a "two way" relationship between intermediate targets for monetary policy and the financial sector. On the one hand, the choice of an intermediate target is not neutral for financial intermediation. For instance, reliance on interest rates will help enhance the efficient allocation of financial resources, but may also generate market risks for financial intermediaries or borrowers. On the other hand, the level of development of the financial sector is not neutral for the choice of an intermediate target. For example, the effectiveness of a monetary target may decline in well developed financial systems in which finance is no longer provided exclusively by banks. However, low credit 
culture and weak competition in the financial sector, may undermine the effectiveness of a monetary framework anchored on prices signals. Therefore, in choosing an intermediate target, the monetary authorities have to strike a balance, which means applying judgment and taking measured risks. The remaining of this section elaborates on China's macroeconomic and financial sector attributes that matter for the design of the monetary policy framework.

\section{A. Macroeconomic Attributes}

China's main challenge is associated with the implementation of a tightly managed exchange rate system in the face of foreign exchange inflows. This has created a conflict for monetary policy which, in particular prevents greater reliance on interest rates to manage aggregate demand given that monetary tightening may result in larger capital inflows. Reliance on administrative controls to restrain credit and investment growth has deflected some of the pressure, and has allowed the PBC to maintain low interest rates. However, administrative controls are most likely to become less effective as the grip of the state on the financial sector decreases. In particular, the opening up of the financial sector in the context of WTO commitments will lead to a larger role of financial institutions no longer under the control of the authorities and, therefore, less susceptible to comply with moral suasion.

Strong external sector performance and capital inflows, and the policy of keeping the nominal exchange rate stable have resulted in sharp increases in monetary aggregates. Broad money (M2), which includes currency in circulation, savings, time, and other deposits, has been growing beyond the target range (M2 growth during the period 2000-2005 has fluctuated in a 141/2 percent-171/2 percent annual rate range, with a maximum of 19.6 percent in 2003). As it is discussed in Section IV, the instability of the money multiplier for M2 turns the issue of controlling the monetary aggregate even more problematic.

Responding to these monetary developments, the PBC has increased the benchmark rates for banks' loans and deposits. ${ }^{3}$ Although the PBC's money market operations are far from effective against the large liquidity surplus in the money market, the central bank was able to successfully smooth out seasonal variations of excess reserves (see Figure 1). Against that background, the authorities' response to contain the potential risks to macroeconomic stability of high money growth have included sterilization operations, higher reserve requirements, ${ }^{4}$ and recourse to administrative controls and lending guidance (see Section III).

\footnotetext{
${ }^{3}$ In April and August 2006 the PBC raised the benchmark rates for banks' loans, and in August 2006 it also raised the benchmark deposit rate.

${ }^{4}$ The PBC reversed its policy of lowering the reserve requirement ratio from a peak of 13 percent to 8 percent in November 1999. Starting in 2003 the PBC increased the ratio to the current level of 9.5 percent for large state-owned banks and joint-stock banks and 10 percent for smaller institutions.
} 
Figure 1. China: Selected Macroeconomic Indicators
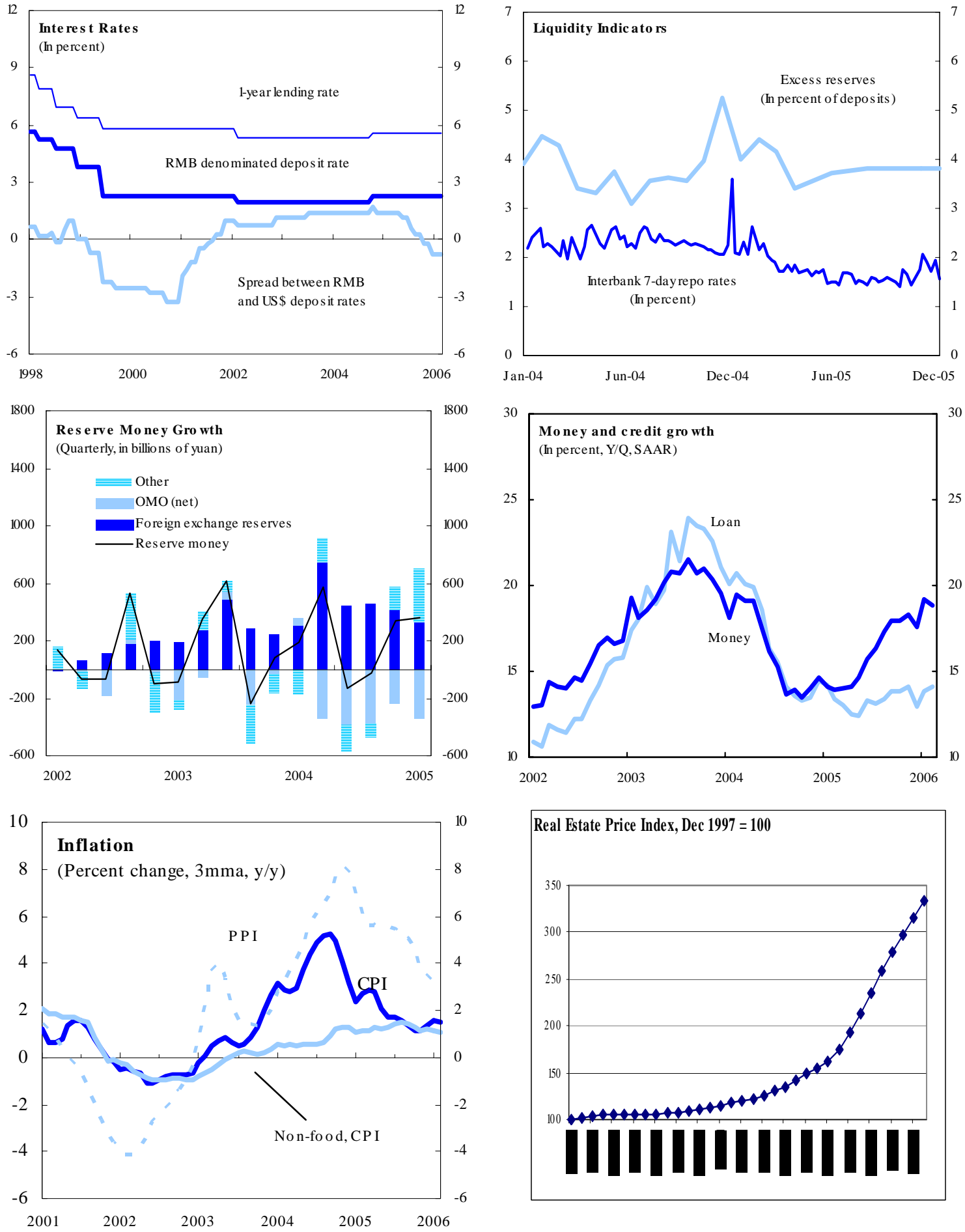

Source: National Bureau of Statistics of China and staff estimates. 
So far, the PBC has managed to contain the cost of sterilization operations associated with international reserves accumulation. OMO became, since 1999, the main instrument to influence reserve money. The cost of sterilization operations has been kept low thanks to the restrictions on the capital account that have allowed interest rates in China to diverge significantly from interest rates overseas. In particular, this has allowed the PBC to sell central bank securities to the state-owned banks at interest rates that are lower than the average return on international reserves. ${ }^{5}$

However, rapid credit growth and sharp increases in real estate prices are areas of concern. Although the growth in property prices has eased, the credit growth is accelerating further. Housing prices increased by a nationwide average of 14.4 percent in 2004 but they have later decreased to a plateau of around 6 percent in response to control measures introduced by the government. ${ }^{6}$ Based on a more cautious lending by restructured state-owned commercial banks and on moral suasion, credit growth remained relatively subdued in the second part of 2005 but has since increased.

Against the backdrop of the above macroeconomic attributes, the number of policy objectives assigned to the central bank further complicates monetary policy implementation. In particular, China finds hard to simultaneously maintain a managed (fixed) exchange rate regime, cope with capital inflows and pursue an independent monetary policy that targets money. This "impossible trinity" suggests that the country can not achieve multiple targets without further complicating monetary policy conduct and foreign exchange operations.?

\section{B. Financial Sector Attributes}

The banking sector dominates China's financial sector and it is growing fast. Most financial intermediation is carried out by commercial banks, which intermediate nearly 75 percent of the capital in the economy. ${ }^{8}$ In 2003, the increase in domestic and foreign currency loans made by financial institutions was equivalent to 23 percent of GDP, compared with funds raised through the stock markets or corporate bond issuance of only 1 percent and 0.3 percent, respectively. The banking sector is also growing at a brisk pace, due to the high

\footnotetext{
${ }^{5}$ Moral suasion may have also helped contain the cost of sterilization.

${ }^{6}$ Source: Oxford Analyitica and National Bureau of Statistics. The authorities modified the housing loan policy in an effort to promote risk awareness of borrowers. In March 2005, the PBC eliminated the preferential interest rate on housing loans and imposed a lower limit of 0.9 times the benchmark lending rate with the same maturity, and it raised the down payment on consumer housing loans from 20 percent to 30 percent in cities and areas where real estate prices are considered to be rising too fast. In June 2006 the China Banking Regulatory Commission ruled that banks may lend only 70 percent of house value to individual buyers, down from 80 percent (Green, 2006). These adjustments are expected to stabilize housing prices.

${ }^{7}$ Appendix II describes some policy responses by a group of countries that faced capital inflows. Most countries have responded with a combination of steps including, in all cases, greater exchange rate flexibility.

${ }^{8}$ See McKinsey Global Institute (2006).
} 
saving rate, depositor confidence and the lack of other investment vehicles and instruments (China's equity and bond markets are among the smallest in the world). As a consequence, the ratio of credit to GDP is among the highest across a broad sample of economies and has also grown substantially since the mid-1990s. ${ }^{9}$

The banking sector has been undergoing a gradual transition toward market principles, but its stability is not well ensured. ${ }^{10}$ Important steps were taken to upgrade prudential regulations, assess asset quality and provisioning, strengthen lending practices, improve accounting and disclosure standards. However, clear evidence that the dominant state-owned banks have substantially changed their behavior and became market oriented is unclear. Three of the four dominant state-owned commercial banks have been restructured, but it will inevitably take time before fundamental changes of behavior can take root. ${ }^{11}$ Given the crucial role played by the banking sector in the financial system, its soundness and well-functioning are critical to ensure macroeconomic stability, and strong incentives for banks to base their decisions on commercial principles will be needed. ${ }^{12}$

Capital allocation in the system appears to be suboptimal. Wholly and partially state-owned companies continue to absorb most of the funding from the financial system, while private enterprises, the engine of China's growth (which accounts for 52 percent of GDP), receives a disproportionately small share of total credit (only 27 percent). In addition, a low equity market capitalization and a small number of corporate bond issues inhibit funding to large private companies and productive infrastructure projects, thus generating a misallocation of capital, as evidenced by the high levels of nonperforming loans (NPLs) and contingent liabilities. ${ }^{13}$ A recent study by McKinsey \& Company suggests that China’s investment efficiency has been declining. The study estimates that the investment needed to produce US\$1.00 of GDP increased from US\$3.30 in the first half of the 1990s US\$4.90 since 2001, that is 40 percent more than required by other Asian emerging market economies in their high-growth periods. ${ }^{14}$

\footnotetext{
${ }^{9}$ As of end 2002, the ratio of domestic credit to GDP was above 160 percent in China, compared to 140 percent in Japan, and less than 100 percent in the United States and Asian emerging markets (Prasad, 2004). Bank credit to nongovernment entities represents more than 100 percent of GDP.

${ }^{10}$ Karacadag (2003), Barnett (2004) and Podpiera (2006) review banking sector developments in China.

${ }^{11}$ Bank restructuring involved China Construction Bank, Bank of China, and the Industrial and Commercial Bank of China. All three banks are also raising capital through IPO issuance. Reforms at the Agricultural Bank of China, the fourth state-owned bank, are still pending. See Karacadag (2003) and Podpiera (2006).

12 See Podpiera (2006).

13 The ratio of NPLs to total loans reported by the authorities declined to 13 percent in 2004 and reached 7.5 percent at end-September 2006. Some financial analysts place the NPLs ratio at a much higher level.

${ }^{14}$ See McKinsey Global Institute (2006).
} 
In view of the above attributes for the financial sector, there seems to be ample room to ensure a more efficient allocation of savings (capital), through greater reliance on interest rates in the conduct of monetary policy (while avoiding destabilizing the banking sector) and further used of market-oriented instruments to manage credit and investment growth.

\section{Current Frameworks For Monetary Policy}

China's monetary policy frameworks have evolved through different arrangements in the last three decades. China's experience with monetary targeting is assessed in the next section with a particular focus on the strategic framework that has been in place since late 1994 . Thereafter, some operational issues are discussed including progress made in the liberalization of interest rates since the November 1993 milestone decisions of the Third Plenum, and progress made in developing nation-wide money and foreign exchange markets as well as instruments and arrangements for managing systemic liquidity.

\section{A. China's Experience with Monetary Targeting}

China started moving to a monetary strategy anchored on intermediate monetary targets in the late 1980s. Until 1986, China relied on a centrally-planned economic system with no explicit intermediate monetary targets. During the period 1986-1993, targets on currency in circulation and on banks' loan portfolio were adopted as intermediate targets. Until 1993, monetary policy pursued dual goals of achieving currency stability and promoting economic development. In December 1993, the State Council established that the goals of monetary policy were to maintain the stability of the value of the currency and thereby promote economic growth.

A second phase of monetary targeting began in September 1994 when the PBC defined and announced three layers of money supply indicators, M0, M1, and M2. In 1996, the PBC formally treated money supply as an intermediary target, and announced that during the Ninth Five-Year Plan, money supply control targets would be set. The third and current phase started in 1998 when the credit ceilings were eliminated, leaving money supply as the single intermediate target. Under the current framework, the strategic framework for monetary policy is organized around inflation (and thereby growth) as the final target; M2 as the intermediate target, and reserve money as the operating target, with an eye on short-term interbank interest rates, and on the stability of the exchange rate.

The correlation of the intermediate target with real economic activity has not been stable over time. This has resulted in deviations between the announced targets and actual values for monetary aggregates. ${ }^{15}$ During the period 1994-2004, the targeted and actual values fell together only three times in the case of M1 and only four times in the case of M2 aggregate

\footnotetext{
${ }^{15}$ One may also infer that the PBC did not attempt to achieve the targets at all costs.
} 
(Table 1). ${ }^{16}$ Strong deviations of more than four percentage points occurred several times for both M1 and M2. Judged against the lower levels of inflation achieved, this evidence suggests that there exists a wider range of monetary aggregate growth that is consistent with the current levels of inflation. Hence, it seems that at relatively lower levels of inflation, M2 looses relevancy.

Table 1. China: Targeted and Actual Values for Monetary Aggregates, 1994-2004

\begin{tabular}{ccccc}
\hline Year & \multicolumn{2}{c}{$\begin{array}{c}\text { M1 growth } \\
\text { (In percent })\end{array}$} & \multicolumn{2}{c}{$\begin{array}{c}\text { M2 growth } \\
\text { (In percent })\end{array}$} \\
\hline \multicolumn{1}{c}{ Target } & Actual & Target & Actual \\
\hline 1994 & 21 & 26.2 & 24 & 34.5 \\
1995 & $21-23$ & 16.8 & $23-25$ & 29.5 \\
1996 & 18 & 18.9 & 25 & 25.3 \\
1997 & 18 & 16.5 & 23 & 17.3 \\
1998 & 17 & 11.9 & $16-18$ & 15.3 \\
1999 & 14 & 17.7 & $14-15$ & 14.7 \\
2000 & $15-17$ & 16.0 & $14-15$ & 12.3 \\
2001 & $13-14$ & 12.7 & $15-16$ & 14.4 \\
2002 & 13 & 16.8 & 13 & 16.8 \\
2003 & 16 & 18.7 & 16 & 19.6 \\
2004 & 17 & 13.6 & 17 & 14.6 \\
\hline
\end{tabular}

Source: Geiger (2006).

\section{B. China's Experience with Monetary Policy Implementation}

Monetary-and exchange system-reforms in China have emphasized institution building as well as financial markets development. ${ }^{17}$ In the mid-1990s, the development of nation-wide money market became a priority in order to enhance monetary policy effectiveness, and strengthen the foreign exchange market. Inherently related was interest rate liberalization, an area where reforms have generally proceeded at a slow pace, although the unification of the exchange rate in January 1994, and acceptance of the obligations of Article VIII of the IMF's Article of Agreement in December 1996, made domestic interest rate flexibility desirable as a tool to support the exchange rate. Interest rate reforms were supported by the November 1993 milestone decision of the Third Plenum, which outlined a strategy in which financial reforms were to be a key element of macroeconomic management in a market environment.

While significant progress was made since the November 1993 decision, the agenda outlined at the time has not yet been completed: interest rates are not yet fully liberalized (see below) and the market infrastructure has been upgraded but the money market is segmented.

\footnotetext{
${ }^{16}$ Lardy (2005) argues that against the stability of the nominal exchange rate over the past nine years, much of the overshooting of the monetary targets aimed, explicitly, at supporting job growth. He also warns that the over-expansion in 2002-03 was an over-reaction to the potential adverse effects of SARs on economic growth.

${ }^{17}$ See Mehran, Laurens and Quintyn (1996).
} 


\section{Interest rate liberalization}

An emphasis on the risks of financial sector reform leads to placing interest rates liberalization relatively late in the sequence of economic reform and to favoring a gradual approach (i.e., waiting to see the outcome of the previous reforms before embarking on the next steps). Gradualism has been possible because, given a high savings ratio, avoiding distortions may have not been critical to savings mobilization and high growth rates were achieved with relatively low efficiency in resource allocation. In any event, real interest rates have tended to be positive, which is atypical of a financially repressed system.

The basic scheme for liberalizing interest rates was laid out in November 1993 at the Third Plenary Session of the Fourteenth Communist Party Central Committee. In 2002, the report of the Sixteenth National Congress reiterated the need to advance interest rate market reforms and optimize financial resource allocation. In 2003, the Third Plenary Session of the Sixteenth Central Committee pointed to the need to establish a robust mechanism for marketbased interest rates, and monetary policy actions to steer them in a direction consistent with economic objectives.

The sequencing of interest rates liberalization was carefully crafted. It involved first lifting restrictions on wholesale transactions then gradually liberalizing retail transactions. Deposit and lending interest rate on foreign currencies were liberalized before those on local currency, starting with loans followed by deposits, and with long term and large amounts first, followed by short term and small amounts. Beginning in 1996, restrictions started to be lifted on wholesale transactions, including bond and interbank market operations. The measures included liberalizing interbank market rates; liberalizing the primary market for government securities; adjusting the $\mathrm{PBC}$ refinancing rate and make it a reference rate for the money market. Wholesale transactions are now fully liberalized, as well as interest rates on foreign currency denominated instruments.

Regarding retail banking operations, the sequence involved first allowing banks to price counterparty risks on customers within a floating margin, then fully liberalize lending and deposit rates (see Mehran et al. 1996). The authorities first reduced the number of administered interest rates; adjusted bank lending rates to industrial and commercial enterprises more frequently to reflect changes in the PBC reference rate; and allowed financial institutions to price their lending operations within a floating margin. ${ }^{18}$ In 2004 , important steps were made with respect to retail operations, leading eventually, in October 2004, to the removal of ceilings on lending rates and of a floor on deposit rates. However, a floor was retained for lending rates, and a ceiling for deposit rates, differentiated by maturity

\footnotetext{
${ }^{18}$ The liberalization of lending rates was not always smooth. In 1987 banks were allowed to charge higher rates on working capital loans up to 20 percent above the respective ceilings. In May 1996 the margin was reduced to 10 percent to alleviate financial costs to enterprises. In April 1999, the margin was expanded to 30 percent for loans to SMEs but remained at 10 percent for large enterprises (see People’s Bank of China, 2005).
} 
(three, six and 12 months, and two, three, and five years). The rationale of such a rather uncommon mechanism of interest rates controls is to protect banks' intermediation margins. ${ }^{19}$

\section{Impact of financial innovation on interest rate controls}

In addition to the relaxation of the direct controls on banks' deposit and lending rates, financial innovation has provided further scope for market-based funding of corporations. First, the introduction of commercial paper (CP) has allowed large corporations to access funding at money market conditions. Although the primary market for CP is subject to PBC guidance, secondary market trading rates are free. Therefore, there is greater flexibility for pricing short-term financing through the CP market than at the banks' loan market. Hence, while still small compared to the loans market (CP represents only 11 percent of banks' outstanding loan portfolios), the CP market is expanded rapidly (the outstanding balance of CP increased by 51 percent on a year-to-year period in March 2006, compared to 14 percent for banks' loans). When money market rates fall below the floor for banks' loans, corporations with a good rating can borrow at money market conditions through the CP market. $^{20}$

Second, banks' discount operations are not subject to interest rate controls on banks' lending operations. Therefore, banks can make loans to their customers at below the statutory lending rate. Like the CP market, the discount market is expanding rapidly (the outstanding balance of discounted bills increased by 72 percent on a year-to-year period in March 2006). ${ }^{21}$

Third, the liberalization of the foreign exchange swap market in July 2005 (see below), combined with a free current account have opened an avenue for circumventing interest rate regulations. The loopholes exploit the forward premium differential between Non Deliverable Forward (NDF) RMB contracts implied rates and domestic rates. NDF implied interest rates, which happen to be lower than domestic interest rates due to the segmentation created by capital account restrictions, did not represent a real funding alternative so long as market players could not access the spot market. The July 2005 measure has allowed corporations having access to foreign exchange to combine NDF rates and spot operations to construct synthetic RMB borrowing, therefore borrowing at interest rates below domestic market and PBC interest rates. ${ }^{22}$

\footnotetext{
${ }^{19}$ See Zhou (2005) indicating that removing the limits may result in improper market competition. Therefore, they could be maintained for a relatively long period of time before they can be removed.

${ }^{20}$ See People’s Bank of China, 2006 Q1 Monetary Policy Report.

${ }^{21}$ See People’s Bank of China, 2006 Q1 Monetary Policy Report.

${ }^{22}$ At times, the widening spread between NDF implied and domestic rates (because of appreciation pressures on the off-shore market) have allowed corporates operating onshore to raise RMB funding at negative rates.
} 
However anecdotal, these examples highlight that the steps that have been taken to liberalize the money and foreign exchange markets have also contributed to segmenting further those markets. Therefore, the operational framework of the PBC risks loosing effectiveness.

\section{Liquidity management}

The PBC has developed a set of monetary instruments (Box 1) which conform to best practices and which place the $\mathrm{PBC}$ in a relatively strong position to rely primarily on marketbased instruments in the conduct of monetary policy. Open market operations (OMO) in the form of issuance of PBC bills play an important role for the sterilization of excess liquidity, and reserve requirements provide important support to OMOs. So far, the cost of sterilization via OMOs was contained because of a positive differential between foreign and domestic money market rates. However, this policy has involved a cost for the banking sector when banks’ deposit rates have been kept above money market or PBC bills rates (Figure 2).

Figure 2. China: Structure of Interest Rates, 2000-2006

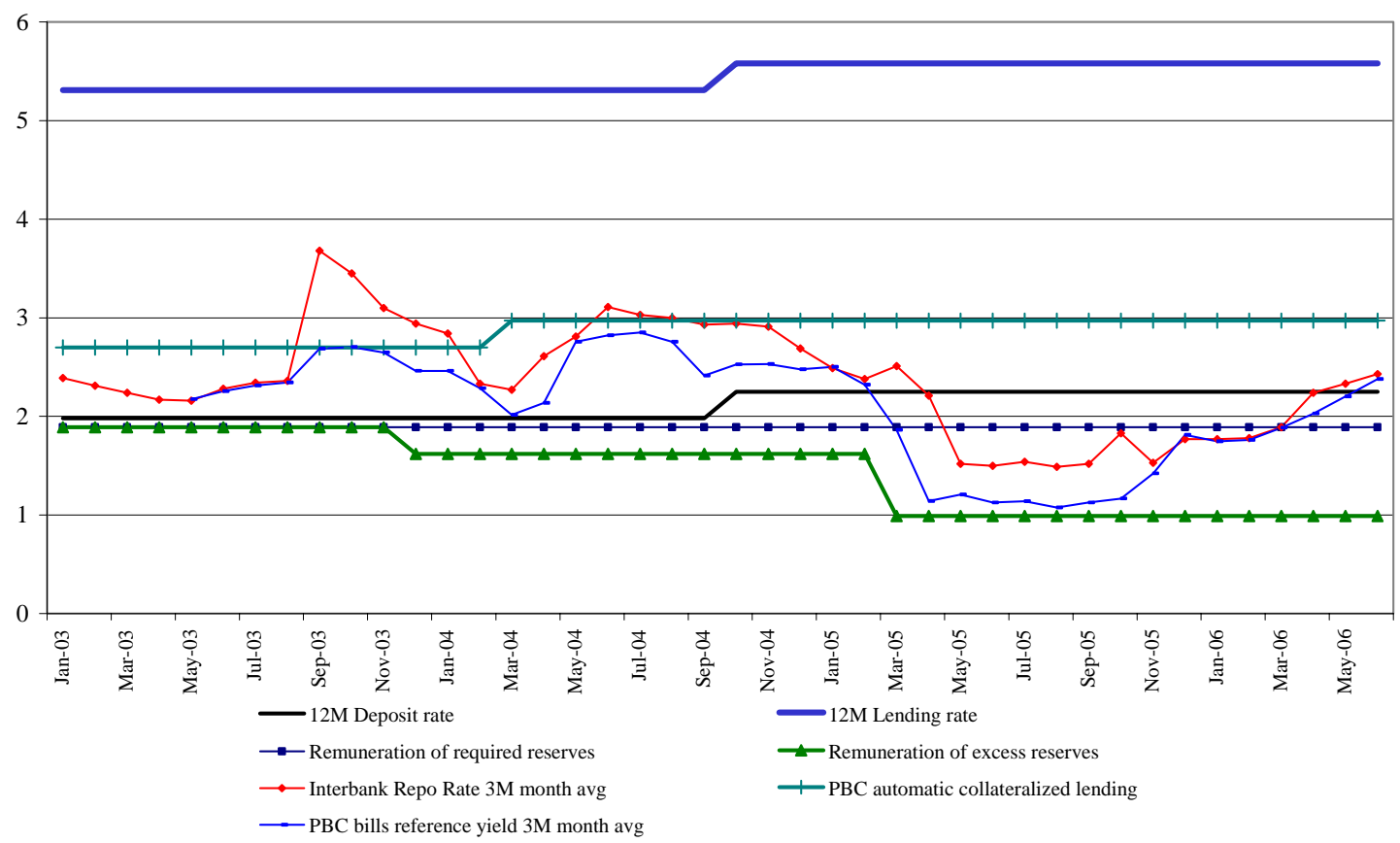

In practice, the $\mathrm{PBC}$ does control short term interest rates in the sense that it controls liquidity conditions in the interbank market, and sets the rates of its bills, the two being related by some arbitrage condition. Indeed, there is a relatively close relationship between the PBC bills rates and short-term interbank repo rates (Fiigure 2), i.e. the PBC rates tend to be "effective" in the money market. However, bank deposit and lending rates (which are also set by the PBC) have been detached from PBC bills rates or money market rates. 


\section{Box 1. China: Main Monetary Policy Instruments}

\section{Standing facilities (SFs)}

The PBC operates the following SFs: (i) automatic collateralized lending (ACL). Banks can obtain liquidity from the PBC at the rediscount rate minus 27 bps if arranged during the trading day (2.97 percent); (ii) excess reserves facility (ERR), which amounts to an automatic deposit facility. Banks' excess reserves are remunerated at a rate that has been lowered in December 2003 from 1.89 to 1.62 percent, and to 0.99 percent in March 2005.

\section{Open market operations (OMO)}

OMO were introduced in 1993, discontinued in 1997, and re-introduced in May 1998, when the PBC started outright transactions on bonds, later replaced by repurchase transactions (repos). In June 2002, the PBC started using reverse t-bonds repos to cope with foreign exchange inflows. In September 2002, when it ran out of t-bonds, the PBC started to auction its own bills, following a transition period during which outstanding repos were converted into PBC bills. OMOs are conducted two (or more) times a week. A primary dealer system in OMO was started in 1998. In December 2005, the PBC made an experimental use of foreign exchange swaps; however it emphasized the anecdotal nature of these transactions.

\section{Reserve requirements (RRs)}

In place since the mid-1980s, the ratio was reduced from a peak of 13 percent to 8 percent in March 1998, and to 6 percent in November 1999. In 2003 and 2004, the PBC raised the RRs ratio to 7 percent and later to 7.5 percent. In April 2004, the PBC adopted a differentiated RRs system: banks with capital adequacy ratios or asset quality below certain standards have to hold higher required reserves. The RRs ratio was raised three times in 2006 (in June, August and November), and again in Junuary 2007 to the current levels of 9.5 percent (10 percent for financial institutions with a weak financial position). RRs are remunerated at 1.89 percent since 1998.

\section{Interest rates controls}

Since October 2004, when the ceiling on banks' lending rates and the floor on their deposit rates were eliminated, banks are subject to a device to protect their intermediation margins: deposit rates are subject to a ceiling, and lending rates to a floor. Since then, the PBC has changed twice (in April and August 2006) the benchmark rates for banks' loans in response to high money and credit growth, and once the benchmark rates for deposits (in August 2006).

\section{Window guidance}

Credit plans were eliminated in 1998 but the PBC convenes financial institutions to provide guidance on credit growth and sectoral allocation. It is believed that window guidance involves lending volume guidelines. As an instrument of monetary policy, Geiger (2006) stresses that window guidance has been relatively successful because the governor of the $\mathrm{PBC}$, in charge of implementing it, is a higher-ranking official than those at commercial banks.

\section{Other administrative measures}

At times, the PBC has been issuing forced PBC bills targeted at commercial banks where loan growth was considered too fast. 
The interaction between the PBC's standing facilities and OMOs is not fully consistent with practices in mature markets. Typically, OMOs aim at creating stable liquidity conditions. In practice that involves steering banks' excess reserves to levels in line with banks' minimum working balances (i.e., avoiding excess reserves). Banks may still be offered the possibility to place excess funds with the central bank through a deposit standing facility, but the central bank would not use that facility to sterilize liquidity on a permanent basis, as is the case in China with the excess reserves facility (ERR), but only to stabilize market rates. ${ }^{23}$

The implication of the current interaction between standing facilities and OMOs is that, would financial institutions be free to price their operations, the short-term money market rate would be close to the ERR, which is obviously not a sensible proposition given its current level. ${ }^{24}$ Hence, the PBC continues to rely on administrative measures: "Window guidance" (i.e., moral suasion) was introduced in 1998, at the time when the PBC eliminated bank-by-bank credit ceilings. This instrument became "institutionalized" starting in June 2003, when the PBC started the guidance process by publishing a notice aimed at curbing the expansion of lending to the real estate sector. Together with the use of the other monetary instruments, the usage of "window guidance" by the PBC is reported to the public in its Quarterly Monetary Policy Reports and website.

\section{Money market development}

China's money market is made of three main sub-markets. The first component is the interbank market, where banks lend funds among themselves from overnight to four months. Trading is concentrated in the one- to seven-day range; the seven-day loan rate is the CHIBOR market's benchmark. The interbank bond market, now the largest bond market, is the second component of the money market where the PBC bills are traded. This is a liquid market, supported by the constant supply of PBC bills (3- to 12-month maturities, and a small number of 3-year bills). The MOF as well as policy and commercial banks issue debt into this market. Finally, the bond repo market, the third component of the money market, is for short-term borrowing. It tends to be less volatile and more liquid than the CHIBOR market. Since 1997, the repo rate has been set by the market and the most active contracts have terms of one-seven days. The seven-day repo is used as a benchmark rate.

Regulatory limitations have been a source of segmentation between the sub-markets. In particular, disorders in the financial industry in the early 1990s motivated establishing a separation between securities and banking business, including, at the beginning of 1997, the decision that commercial banks should withdraw from repo trading on the stock exchange, and carry out repo trading on the interbank market only. The fear was that that short-term borrowing by securities companies in the interbank market could lead to contagion, as

\footnotetext{
${ }^{23}$ See Laurens (2005) for a review of the use of instruments at different stages of market development.

${ }^{24}$ The PBC recognizes that the remuneration of excess reserves undermines the effectiveness of monetary policy management. See PBC 2005 Q1 Monetary Policy Report.
} 
changing conditions in the capital market would be directly reflected in changes in the interbank market. ${ }^{25}$ While these restrictions appear to have been relaxed, ${ }^{26}$ current limits on the RMB interbank market activity assigned to commercial banks funded in foreign exchange are still a source of market segmentation. ${ }^{27}$

\section{Foreign exchange market development}

Following the July 21, 2005 announcement of the adoption of new exchange rate arrangement whereby the renminbi value is set with reference to a basket of currencies, the PBC implemented a number of policy measures to enhance the operations of the foreign exchange market including: (i) the introduction of a market-maker system and over-thecounter (OTC) transactions in the spot foreign exchange market, while maintaining the matching system in the Shanghai Foreign Trading System (CFETS). The OTC market is now the backbone of the spot market; ${ }^{28}$ (ii) launching RMB and foreign exchange swaps and RMB interest rate swaps on a pilot basis to improve the pricing mechanism of financial derivatives; (iii) allowing access of more market participants to the foreign exchange market, with 64 member banks dealing in the inter-bank RMB forward market; and (iv) introducing a primary dealer system for PBC foreign exchange transactions, with a view to allow, in due time, a gradual exit strategy of the PBC from the foreign exchange market. ${ }^{29}$

These reforms should enhance the capacity of the PBC to manage the exchange rate with greater flexibility. Greater uncertainty about the exchange rate (although so far the exchange rate has been tightly managed), together with OTC trading should provide incentives to financial institutions to develop risk management tools (settlement arrangements, credit limits, etc) while alleviating the credit risk that is borne by the CFETS. Furthermore, the setting up of market makers for the foreign exchange market is also a constructive development. By providing the market with two-way prices, market makers play an important role in price discovery mechanism and market development. Market makers can also act as the primary counterparts of the PBC in its official intervention, and the PBC can rely on them to collect market intelligence that is not currently available via the CFETS. Therefore, PBC communication and signaling should be facilitated.

\footnotetext{
${ }^{25}$ See Xie Duo, 2002, and Boyreau-Debray and Wei (2004), and Zhou (2006).

${ }^{26}$ In the first quarter of 2006, securities and fund management companies' borrowing in the repo and interbank market amounted respectively to about 20 percent and 40 percent of market turnover.

${ }^{27}$ Foreign banks can only borrow 1.5 times their branch capital in the RMB interbank market.

${ }^{28}$ At the end of March 2006 trading in the OTC market stood around 30 times trading in CFETS.

${ }^{29}$ The primiary dealer system is expected to help strengthen the transmission of the central bank’s policy intentions in its foreign exchange operations as well as the effectiveness of those operations.
} 


\section{Obstacles to the Effectiveness of Interest Rates as an Operating Target}

There are several potential obstacles to the effectiveness of interest rates as an operating target for monetary policy conduct in China. First, some of the attributes of China's economy and financial sector can potentially limit the effectiveness of the interest rate transmission channel for monetary policy in China. Second, one may argue that the PBC does not have yet in place the monetary frameworks and instruments to conduct fully-fledged market- based monetary policy. In the following paragraphs, we discuss those two issues.

\section{Interest rate transmission channel}

The effectiveness of the interest rate transmission channel could be held back due to insufficient progress in establishing a commercially driven financial sector. In particular, the banking sector exhibits several problems that complicate the transmission of monetary policy to the real sector. ${ }^{30}$ First, the restructuring of the banking sector has not been completed yet and there are still some banks with high level of non-performing loans and little capital. Second, banks' operational reforms are only starting and it will take time before they are truly commercially oriented and will be able to price risks properly. Third, there are obstacles to the responsiveness of firms and individuals to the price of capital. Firms, in particular SOEs, may still be operating in the context of the quantitative framework whereby the credit channel was the main means of influencing aggregate demand. Financial and enterprise reforms over the last decade should, however, have meant that the interest rate has more influence, but it is difficult to measure progress in this area. Against this background, one could however argue that greater reliance on price signals in the conduct of monetary policy is precisely what is needed to speed up the "commercialization" of the financial sector.

Another potential obstacle to the effectiveness of the interest rate transmission channel has to do with current market segmentation. First, the 1995 Banking Law established a facto twotier commercial banking system. The Law created commercial banks that are subject to prudential ratios and international standards of portfolio risks, as well as policy lending banks which are not subject to similar regulations. The Law also separates the activities of commercial banking and securities industries by not allowing the former group to engage in trust and investment and stock trading, as well as investing in real estate, NBFI and enterprises. Second, money market segmentation, as explained above, is another obstacle to greater reliance on interest rates. Typically, central banks target a short-term interbank lending rate at which financial institutions trade their balances with the central bank among themselves. In turn, the actions of the central bank in the interbank market can spread to the other components of the financial markets because market participants are typically allowed to operate in several financial markets. As explained above, the limitations in place in China do not allow such arbitrage activities. Therefore, the monetary policy actions of the PBC in the interbank market cannot migrate to the other components of China's financial markets.

\footnotetext{
${ }^{30}$ See Podpiera (2006).
} 
Against that background, one could make the point that market segmentation was a necessary second best solution in support of a monetary policy strategy anchored on administrative measures. A shift away from administrative measures and toward market-based monetary policy implementation would imply lifting the obstacles to financial markets integration.

\section{Monetary frameworks and instruments}

High banks' excess reserves are an obstacle to full reliance on market- based monetary policy. Indeed, while they have declined significantly during the 2000s (Table 2), they stand at a high level. ${ }^{31}$ The PBC seems to be reluctant to accept higher short-term interest rates to be able to drain liquidity aggressively, in order to avoid attracting capital flows, or incurring additional sterilization costs. The repeated increases in the reserve requirement ratio in 2006 should help reduce excess reserves. However, one has to be mindful of the potentially distortionary impact of high ratios, in particular given that the remuneration of required reserves is lower than money market rates. In addition, reliance on reserve requirements does not offer the flexibility of OMOs. Hence, there is a need for additional policy action with a view to better control excess reserves.

Table 2. China: Required and Excess Reserves (2000-2005) (in percent of total bank deposits)

\begin{tabular}{|l|c|c|c|c|c|c|c|}
\hline & 2000 & 2001 & 2002 & 2003 & 2004 & 2005 & June 2006 \\
\hline Required reserves & 6.0 & 6.0 & 6.0 & 7.0 & 7.5 & 7.5 & 8.5 \\
\hline Excess reserves & 7.3 & 6.1 & 5.4 & 5.4 & 5.3 & 3.7 & 3.1 \\
\hline Total reserves & 13.3 & 12.1 & 11.4 & 12.4 & 12.8 & 11.2 & 11.6 \\
\hline
\end{tabular}

Source: PBC and Staff estimates.

A last obstacle to full reliance on market- based monetary policy is the lack of instrument independence at the PBC. ${ }^{32}$ In China, all the decisions regarding the level of the interest rates or of reserve requirement ratios have to be approved by the State Council. Such a framework may not provide all the flexibility that is needed to respond in a timely manner to economic developments. Moreover, the multiplicity of objectives assigned to the PBC, as evidence by the goals assigned to the window guidance, creates "noise" in policy implementation, since interest rate changes may not be consistent with the prevailing monetary policy stance.

\footnotetext{
${ }^{31}$ A level of excess reserves of more than $1 / 3$ of required reserves stands particularly high compared, for instance, to the Euro area, where excess reserves amount to less than 1 percent of required reserves.

${ }^{32}$ See People’s Bank of China (2005).
} 


\section{MONEY AS AN INTERMEdIATE TARGET: EMPIRICAL EVIDENCE FOR CHINA}

In this section, we present the results of empirical research on the reliability of money as an intermediate target. We survey recent research advanced by Chinese and other international experts. Then, we present some results of our own empirical research.

\section{A. Survey of Previous Research}

Xie (2004) analyses China’s monetary policy for the period 1998-2002. Using correlation analysis and Granger-causality tests he finds a strong relationship between base money and broader monetary aggregates (M1 and M2) and that, to some extent, money supply is endogenously determined. Using a conintegrated vector autoregression and a vector errorcorrection model, Xie investigates the relationship between money supply, inflation and economic growth. He concludes that within a long-term horizon, monetary aggregates do not affect economic growth, but do determine the inflation rate in both the short and long term.

In its 2005 Q1 Monetary Policy Report, the PBC reports on the stability of the relationship between money supply, economic growth and price stability for the period 1980-2003, during which China experienced four episodes of inflation and one of deflation. During these episodes money supply and output moved in parallel. When money supply expanded to approach a certain level, prices rose and economic imbalance emerged, then a passive adjustment was enforced to tighten money and credit: (i) in the 1980's, annual growth of money supply and GDP averaged 24.5 percent and 9.8 percent respectively, and inflation reached 7.5 percent; (ii) in the 1990's, average annual growth of money supply and GDP stood at 24.9 percent and 9.7 percent respectively, while inflation recorded 7.8 percent; and (iii) during 2000-2004, average annual growth of money supply and GDP were 15.9 percent and 8.9 percent respectively, and inflation stood at 1.1 percent. China experienced financial deepening and a decline in money velocity despite periodic fluctuations: velocity rose as economic growth accelerated, and moderated as economic growth slowed.

In a 2006 paper covering the period 1994-2002, Geiger (2006) analyses the effectiveness of China's monetary policy. He attempts to answer the question whether monetary variables have a close relationship to inflation, and whether inflation can be controlled via the PBC's monetary policy instruments. Geiger first makes the point that money and credit targets were missed frequently (Table 1), and he finds a weak relationship between the intermediate target and the interest rate thus suggesting that there is no functional interest rate channel as the transmission mechanism of monetary impulses in China. He observes that (i) the inflation objective was met even during the 1993-1994 overheating episode; (ii) price stability was maintained subsequently; and (iii) inflationary pressures during 2003-2004 were contained.

Geiger assigns these achievements to a well managed mix of price- and quantity-based measures. The study points to the role of wage controls for inflation control in the mid1990s, although more recently, wage increases in certain regions are threatening to undermine the low inflation wage set up. It is estimated that up to 24 percent of the CPI can be influenced through price controls. The study shows that window guidance during the 2003 
2004 expansionary economic cycle was critical for the successful outcome in the absence of a well-functioning interest rate channel of monetary transmission.

The study concludes that monetary indicators (as intermediate targets) remain relevant given the vague relationship between interest rates and inflation; interest rates should only be supportive rather than a leading instrument. In particular, he hints that an important reason for the use of monetary targeting is the search of a nominal anchor. Geiger notes that distortions are preventing the interest rate channel from functioning. Rather than pointing against the adoption of a short-term interest rate as the operational target of monetary policy, this points to the need to strengthen the interest rate transmission channel. Indeed, only then a price-based monetary strategy, as it was officially introduced in 1998, can be successful.

Green and Chang (2006) ran a regression between reserve money and foreign exchange inflows for the period January 2003 March 2006 to assess the controllability of reserve money and M2. They found that changes in the adjusted inflows explained 78 percent of the changes in reserve money, suggesting that the $\mathrm{PBC}$ is able to control reserve money. They ran a regression between reserve money and $\mathrm{M} 2$ and found that they were not closely correlated. Therefore, even if the PBC can control reserve money, it does not have an easy way of managing M2, due to an unstable multiplier. They found that bank loans were an accurate predictor of M2 in the short-run, with the impact fading after five months. They found also a relationship between M2 growth and bank loan growth, with demand deposits having the largest impact on lending. However, they noted that M2 growth had accelerated in recent months, while bank loan growth has more or less stabilized. This may reflect increased disintermediation due to the development of commercial paper or informal financial sector lending, in response to PBC window guidance during 2005-2006. These findings suggest that even if bank lending is under control, M2 may not automatically follow.

\section{B. New Empirical Evidence}

The use of money as an intermediate target demands the fulfillment of certain conditions. Money should also be in a relatively stable relationship with the final goal of monetary policy. Also, an effective intermediate target should encompass all necessary information to facilitate the inflation forecasting process. In particular, we start by analyzing the stability of the velocity of money by considering the behavior of money and prices since 1994. Figure 3 plots the annual inflation rates and the annual growth rates of M1 and M2. It suggests that changes in monetary aggregates have not behaved in a similar pattern with the inflation rate. 
Figure 3. China: Inflation and Money Growth, 1994-2006

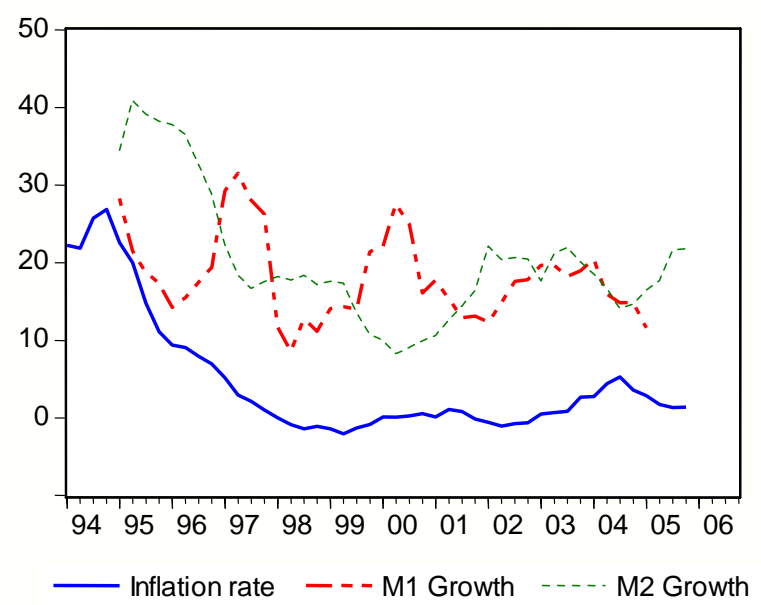

Source: National Bureau of Statistics of China.

As inflation pressures are diminishing, the informative role of monetary aggregates like M1 and M2 falls. Estrella and Mishkin (1997) argue that it is because of the noise caused by velocity shocks and the instability of money demand that arises from structural changes in financial systems. Against this background, many central banks have exited from monetary targeting in the last two decades. As an additional example, based on the limited (short) data set used, Figure 4 plots both monetary aggregates by using a Kernel graph against the inflation rate which shows that the association between inflation and M1 and M2 is high when the inflation rate is high. However, at lower rates of inflation the association looses its strength. Even where there is a clear long-run relationship between money and inflation, in the short run the relationship may not be stable. Therefore, reliance on a monetary program should not be overly rigid. It should also involve a monitoring of a wide range of indicators to gauge the suitability of correcting a deviation from the initial assumptions and eventually shifting from a target to a reference value. ${ }^{33}$

\footnotetext{
${ }^{33}$ Obviously, the relationship between inflation and changes in M2 involves a lag. We have estimated a moneyprice equation by using a distributed lag model in the form of $\pi=c+\sum_{i=0}^{20} \beta_{i} M \dot{2}_{-i}$ where $\pi$ is the inflation

rate, $c$ is a constant, and $M 2$ represents the annual rate of change in M2. The effect of a 1 percent change in M2 can be observed over 20 quarters. The long-run impact of such a change is 0.993 (statistically significant at $t=3.014$ ). Thus, in the long-run a money supply increase is followed by a similar increase in prices. However, the short run impact (elasticity of money supply) fluctuates around 0.05 thus confirming previous results.
} 
Figure 4. China: Inflation and Money Growth—Kernel Graph, 1994-2006
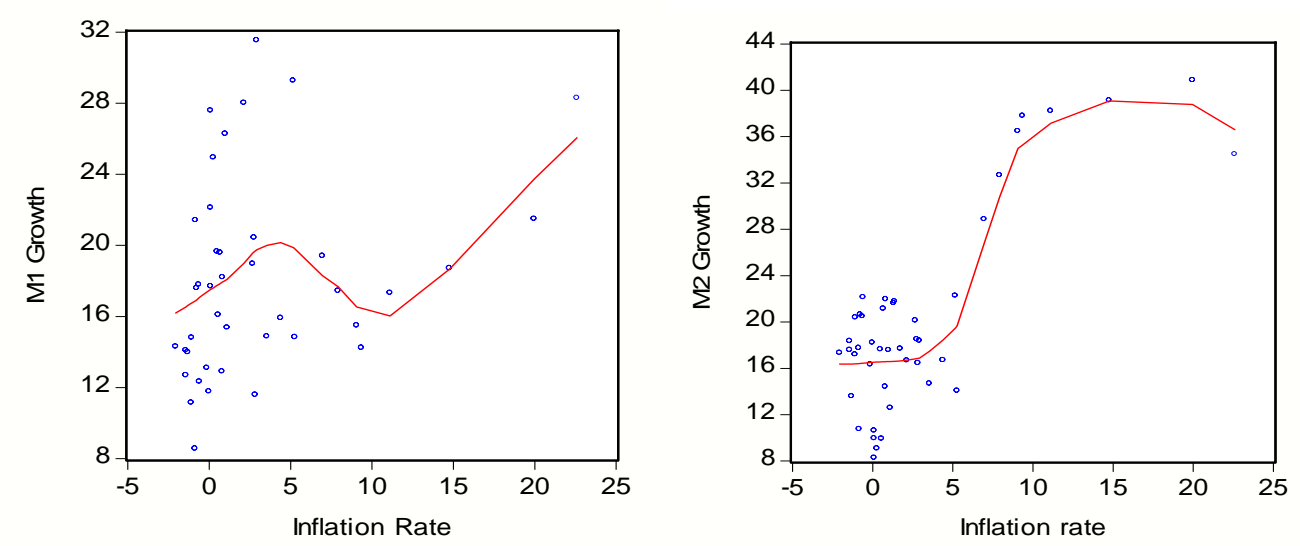

Source: Author's calculations

By controlling the monetary base, the PBC sought to control M2. However, confirming the findings by Green and Chang (2006), the money multiplier has proved to be unstable and not reliable to control M2 given the abrupt changes in its behavior (Figure 5).

Figure 5. China: Money Multiplier

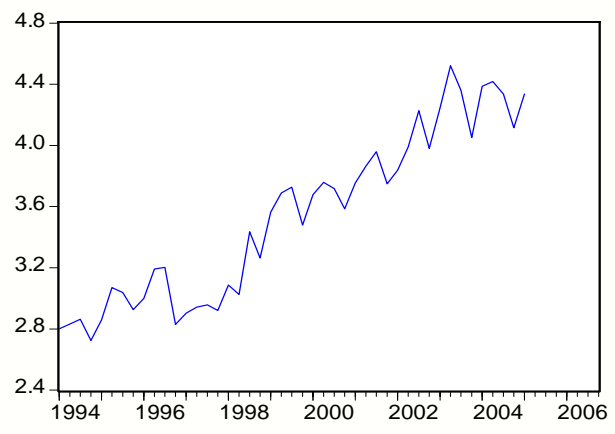

Source: Author’s calculations.

The Augmented Dickey-Fueller (ADF) Test provides intuition about the reliability of the multiplier for monetary policy conduct. The ADF statistic value for the series is -1.059 and the associated one-sided p-value (for a test with 40 observations) is 0.7223 . The statistic value is greater than the critical values at the 1.5 and 10 percent levels so that we can not reject the null hypothesis (the multiplier having a unit root) at conventional test sizes. Conceptually, we can not reject the idea that a shock or innovation in the series is permanent.

The velocity at which money rotates also poses problems for monetary policy conduct. Based on a univariate time series analysis (unit root tests) we reject the stationarity of the income velocity of M2. Being non-stationary, velocity would deviate from the trend over time. The velocity of money shows a trend of irregular deceleration since 1994 which perhaps 
contributed to the PBC inability to achieve its money targets. The trend might be related to the decrease in the opportunity costs of holding money (inflation and interest rates) and the (slow) technological progress related to payments instruments. However (see Appendix III), money demand seems to be a stable function of GDP, interest rate and inflation in the long run. Moreover, monetization is increasing: the demand for nominal money more than fully adjusts to prices in the long run so that the desired level of real balances increased.

The use of a nominal anchor in China is illustrated with a stylized model of inflation. ${ }^{34}$ A time series model is advanced where the variability of inflation depends on long-run inflation, its persistence, and the variability of the shocks affecting it,

$$
\pi_{t}=(1-\phi) \pi^{*}+\phi \pi_{t-1}+\omega_{t}
$$

where $\pi^{*}$ represents long-run inflation rate (target rate), $\phi$ captures the persistence of shocks to inflation $(|\phi|<1)$, the error term $\omega$, represents uncorrelated inflation shocks distributed with mean zero and standard deviation $\sigma_{\omega} \cdot{ }^{35}$ The variability of inflation is given by,

$$
\sigma_{\pi}=\frac{\sigma_{\omega}}{\left(1-\phi^{2}\right)}
$$

The results are shown in Table 3. The standard deviation of inflation shocks is low (1.01 percent). The inflation process, however, is highly persistent (0.92).

Table 3. China: Persistence and Variability of Inflation, 1994-2004

\begin{tabular}{cccc}
\hline \multicolumn{3}{c}{ Parameters } & Memo Item \\
\hline$\pi^{*}$ & $\phi$ & $\sigma_{\omega}$ & $\sigma_{\pi}$ \\
2.0 & 0.92 & 1.01 & 6.52 \\
\hline
\end{tabular}

Source: Authors' calculations based on quarterly data.

Selecting a nominal anchor would involve determining restrictions on the parameters of equation $1, \pi^{*}, \phi, \sigma_{\omega}$. Any announcement on inflation expectations (targets) should be credible in order to act as a nominal anchor. In China, constraints on nominal variables such as the nominal exchange rate or the nominal stock of money have been extensively used as

\footnotetext{
${ }^{34}$ A nominal anchor is a nominal variable that policymakers use to tie down the price level. Its role is two-fold, (i) help promote price stability; and (ii) limit the time-inconsistency problem of discretionary monetary policy. A credible nominal anchor is important to control inflationary expectations and provide confidence in monetary policy whereby agents can distinguish between movements in relative prices (necessary for consumption and investment decision making) and those associated with the price level.

${ }^{35}$ Data corresponds to the International Financial Statistics, various issues. A smooth estimate of the long-term trend component of inflation is obtained by means of a Hodrick-Prescott filter.
} 
anchors since the 1990s. A credible commitment to inflation control may advance clear constraints on $\phi$ and $\sigma_{\omega}$ by relying on forward-looking monetary policy that reacts to future inflationary pressures.

\section{Some Evidence from VARs}

To assess the effects of monetary policy and other policy-related variables on output, exchange rate and prices, we have estimated a five-variable Vector Autoregression (VAR) model to characterize monetary policy and study the impact of the money on inflation and output for the period 1994-2005, quarterly. A VAR methodology places minimal restrictions on how monetary shocks affect the economy, and hence, it seems suitable for monetary time series available. The model can be represented by an unrestricted form such as,

$y_{t}=A(L) y_{t}+u_{t}$

where $y_{t}$ is a vector including endogenous variables (log of real GDP, CPI, exchange rate, short-term interest rate, monetary aggregate, M2, federal funds rates); A(L) corresponds to the matrices of coefficients to be estimated whose lag lengths are usually determined by Schwartz and AIC criteria, and $u_{t}$ represents a vector of innovations that may be contemporaneously correlated and uncorrelated with their own lagged values and their righthand side variables. ${ }^{36}$

Figure 6. China: Response of Prices and GDP to one SD Money Innovation
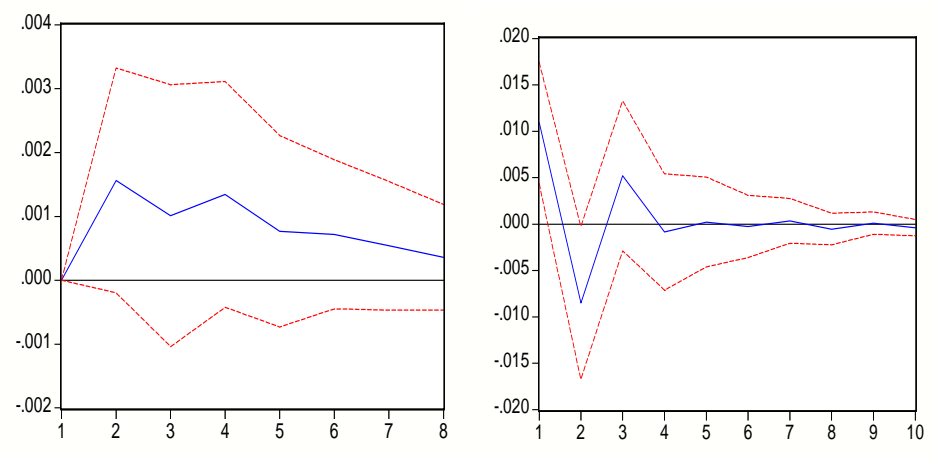

Source: Authors' calculations.

\footnotetext{
${ }^{36}$ It was found that the ordering of the variables for the impulse response functions has little effect and the Choleski responses are very similar to unrestricted responses. To double check this result we note that the correlation matrix of the VAR residuals is close to diagonal.
} 
Figure 7. China: Response of GDP to one SD Interest Rate Innovation

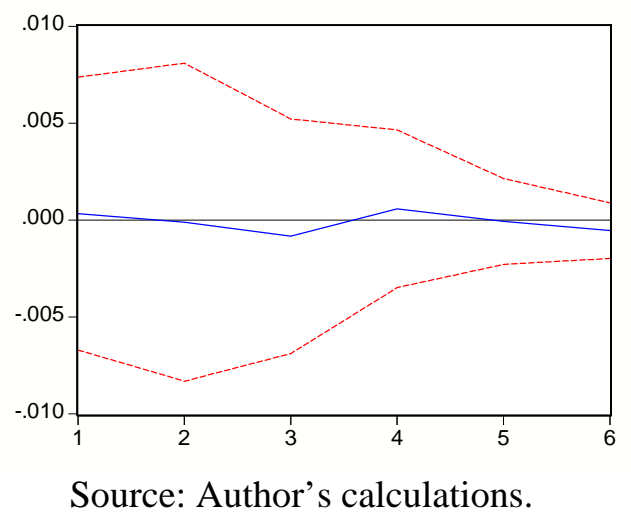

Estimates from this VAR are described in Figures $6-7 \cdot{ }^{37}$ Figure 6 shows a sudden reaction of prices to a disturbance in money, although the impact tends to moderate in the medium term. In particular, the results show the persistence, long-lived, of a money shock on inflation: confirming the significant influence of money in determining inflation, as implicitly implicated by Geiger (2006). Also, money does not have any long run real effect on output. It has to be acknowledged that the limited data set used for the study might have caused significant standard errors urging us to adopt a cautionary tone in presenting the results.

The impact of interest rate changes depends on the ease of propagation of the effect of monetary tightening as well as on agents' reactions. A key aspect is the extent to which a change in the central bank policy rate affects the term structure of interest rates (the yield curve) — especially short-term money market rates, and long-term rates. Monetary policy transmission along the yield curve heavily depends on the structure and organization of financial markets, with deeper markets allowing for more rapid and predictable transmission. As for the impact, the balance sheet positions of economic agents influence the relative importance of marginal and average interest rates effects. Clearly, an interest rate cut reduces the marginal cost of borrowing, which boosts current spending, hence aggregate demand. In addition, rising average interest rates reduce cash-flow and spending, but raise savings. With the caveat that the time series used are of short-term nature, Figure 7 shows the accumulated response of GDP to an innovation in the interest rate, thereby confirming the low impact of changes in interest rates on macroeconomic variables as suggested by Geiger (2006).

\footnotetext{
${ }^{37}$ In Figures 6 and 7, the dotted lines represent 90 percent confidence intervals. The vertical axis shows the deviation from the baseline level of the target variable in response to a one standard deviation (SD) change to the shock variable, while the horizontal axis presents the number of months elapsed after the shock.
} 


\section{THE WAY FORWARD}

\section{A. General Considerations}

\section{Choice of a strategic framework}

In the 1970s, central banks in industrial countries started to move from a reliance on credit or interest rate controls toward a reliance on money market operations (i.e., exchanging financial assets — domestic assets or foreign exchange - for their own liabilities), supported by reserve requirements. ${ }^{38}$ This was a result of the increasing inefficiency of credit and interest rate controls in a context where financial markets had become more integrated both domestically and internationally. In addition, allowing market forces to distribute financial resources was associated with increased economic efficiency and growth. By relying on money market operations, the central bank seeks to exploit its monopoly in base money creation to regulate overall liquidity conditions in the economy by influencing the underlying demand and supply conditions for central bank money.

When conducting money market operations, the central bank either can set the price or target the quantity of base money provided to the system. A lack of developed markets, and the corresponding lack of reliable price information, may force the central bank to rely on quantities (money, credit, or components of its balance sheet) as indicators or intermediate targets for monetary policy. ${ }^{39}$ Furthermore, a drawback of attempting to target interest rates in shallow markets is that the historical absence of market-determined rates leaves the linkages between short-term rates and money and inflation less clearly understood.

At the same time, in the early stages of financial reforms, decisions to modify official interest rates may be politically charged, even if the central bank has full authority to adjust its policy rates, and this can cause rigidity in the upward movement of rates. Therefore, a monetary aggregate may be a superior operating target than a short-term interest rate. In addition, when the analytical capacity of the central bank is limited, the balance is likely to be tipped further away from anchors that rely on fine, well-informed judgments and toward relatively simpler, rules-based frameworks. Hence, simple money or exchange rate rules may be the preferred option for anchoring monetary policy.

Despite their appeal in countries with shallow markets, simple quantity-based frameworks may not perform well in handling shocks and may be sensitive to errors in assumptions about the demand for money. Although there is a long-term relationship between money growth and inflation, in the short-term, the reliability of targeting credit aggregates or the monetary base as a means to manage the central bank's balance sheet depends on the stability of their relationship to the ultimate monetary policy target. Therefore, reliance on a monetary

\footnotetext{
${ }^{38}$ See Laurens (2005).

${ }^{39}$ See Schaechter (2001) and Bindseil (2004).
} 
program should not be rigid and should be accompanied by a monitoring of indicators to gauge the appropriateness of correcting deviations from initial assumptions. ${ }^{40}$ Eventually, uncertainties with regard to the stability of money or credit aggregates with the ultimate monetary policy target have led central banks to migrate away from simple rules-based monetary frameworks (pegged exchange regimes or monetary targeting) and toward frameworks based on informed judgments by the central bank (monitoring a set of indicators and inflation targeting).

Such moves have typically occurred when financial markets had reached a sufficient level of development and the central bank had a research capacity in monetary and economic analysis. Although an explicit inflation target could help stabilize inflation expectations, a framework exclusively centered on inflation is difficult to implement unless the central bank enjoys a high level of autonomy and has developed an inflation forecasting capacity, and the financial sector is developed (Box 2). ${ }^{41}$

Whichever anchoring strategy is adopted (monitoring a set of indicators or explicit inflation targeting) there is a broad consensus among central bankers

\section{Box 2. Initial Conditions for Inflation Targeting}

The initial conditions for inflation targeting can be divided into four groups. First is a mandate to pursue an inflation objective and accountability by the central bank for meeting this objective, autonomy to set monetary instruments accordingly, and transparency in policy formulation and implementation. Second, there is a need to ensure that the inflation target will not be subordinated to other objectives, and the external position is stable to enable monetary policy to focus on achieving the inflation target. Third, the financial system should be developed and stable enough so that monetary policy is not sidetracked by concerns about the health of financial institutions. Markets should be sufficiently developed to enable reliance on marketbased monetary instruments. Fourth, the central bank needs the proper policy tools to influence inflation on the basis of a reasonable understanding of the links between the stance of policy and inflation.

Source: Schaechter (2002). that monetary policy is about setting the level of short-term market interest rates. ${ }^{42}$ Typically, the central bank's decisions aim at the maintenance of price stability. The chain of causality linking the central bank's policy decisions with the price level starts with a change in interest rates that the central bank uses in its monetary operations. The central bank seeks to exploit its monopoly in the creation of base money to regulate overall liquidity conditions in the economy by influencing the underlying demand and supply conditions for base money. Through this process, the central bank can steer short-term money market interest rates effectively. Since the central bank thereby affects the funding cost of liquidity for banks, banks need to pass on these costs to their customers.

\footnotetext{
${ }^{40}$ See Appendix IV for a review of financial and monetary indicators.

${ }^{41}$ See Arnone, Laurens and Segalotto (2006a) and (2006b) for a survey of central bank autonomy indicators and progress made on central bank autonomy in OECD, developing and emerging market economies.

42 See Bindseil (2004), European Central Bank (2004), and Laurens (2005).
} 
Particularly important for reliance on monetary frameworks based on informed judgments is an understanding of the process whereby changes in policy interest rates can affect the ultimate objective of price stability. The transmission of policy interest rates to the lending and deposit rates is a complex process which involves a number of factors, not all under the control of the central bank. Therefore, the central bank needs to develop a view about how monetary policy decisions affect developments in the price level, that is an understanding of the channels of transmission of monetary policy to the economy in general and the price level in particular (Figure 8).

Figure 8. Stylized Representation of the Transmission Channels

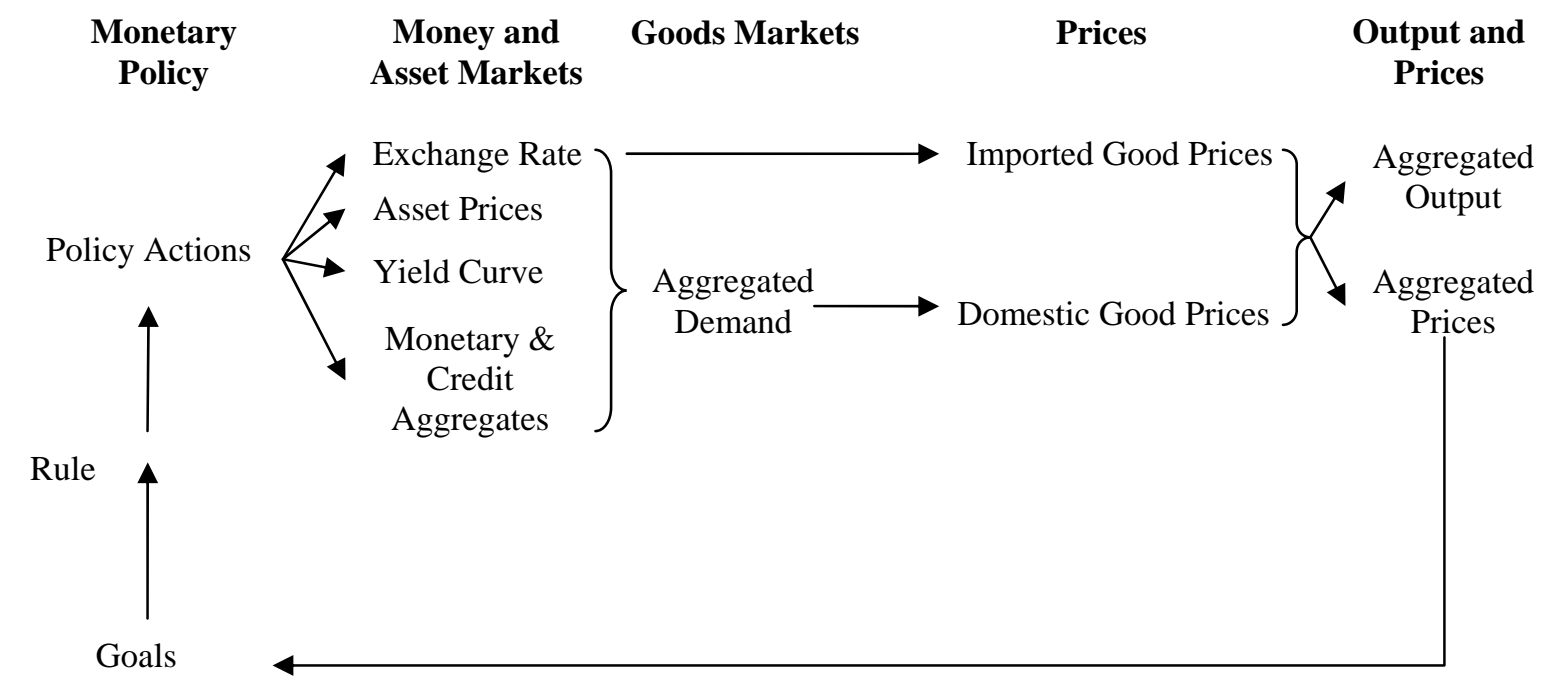

Source: Laurens (2005)

Given the complexity of economic interactions, the central bank often takes into account some simple rules as a guide to policymaking. For instance, the ECB has consistently given credit to the rule that inflation in the medium to long term is a monetary phenomenon and it monitors monetary developments in order to assess inflation trends. ${ }^{43}$ However, the weight to be put on money growth in setting interest rates ultimately is an empirical question. Hence, the central bank should undertake research on the potential role of money (as well as other variables such as credit), both as leading indicator of future economic and inflation developments and as a potential element in the transmission mechanism. ${ }^{44}$

\footnotetext{
${ }^{43}$ See Appendix V for a review of the ECB monetary policy strategy.

${ }^{44}$ Freedman (2006).
} 


\section{Choice of an operational framework}

Today, there is consensus among central banks that the short-term interbank interest rate is the appropriate operational target of monetary policy, and almost all central banks are explicit and transparent about this (Bindseil 2004).

It is also critical to ensure that the functions assigned to various monetary instruments be in accord with the market infrastructure in place and with the institutional capacity of the central bank. The particular combination of instruments will depend on a variety of factors specific to a country's individual circumstances. In general, the mix of instruments depends on the extent of progress with financial reforms and on the depth and liquidity of the money market (which in turn has to do with the soundness of banks). In the early stages of market development, the central bank can rely on liquidity requirements (reserve requirement and liquid asset ratios) and standing facilities, hereafter, collectively referred to as "rules-based instruments." Liquidity requirements can be useful instruments for permanently absorbing liquidity from the market. Standing facilities, which allow banks to deposit funds with or borrow funds from the central bank at their discretion, can play a fine-tuning function. However, the central bank may need to place limits on the ability of individual banks to access its refinance standing facilities so that it can maintain a sufficient degree of control over its balance sheet. Standing facilities and reserve requirements (when they are maintained on average during the maintenance period), can also play a useful buffer function - that is, they can facilitate the operations of the payment systems - in the event of unexpected liquidity shocks, inefficiencies in the redistribution of reserves by the interbank market, or weak liquidity forecasting capacity at the central bank.

For reliance on market-based instruments to be effective, the interbank market should operate smoothly, and the central bank should have developed a liquidity forecasting capacity. An interbank market makes possible the redistribution of banks' reserves, thereby allowing the central bank to manage liquidity a whole, as opposed to managing the liquidity positions of individual banks. A liquidity forecasting capacity allows the central bank to anticipate changes in its balance sheet that would result either in an excessive level of liquidity in the system, which may lead to excessive money creation by the banks, or in a shortage of funds, which may obstruct money market operations.

The speed with which the central bank can shift from administrative measures (window guidance or forced placement of securities) and reduced reliance on reserve requirements, ${ }^{45}$ to greater reliance on market-based instruments depends on progress in strengthening the interbank money market and the central bank's liquidity forecasting framework. In particular, effective liquidity forecasting allows the central bank to make informed decisions about the

\footnotetext{
${ }^{45}$ Reserve requirements can and should probably be retained (most central banks in advanced economies have retained them). However, but their function, when averaging provisions are in place, is to serve as a mecahims to absorb short-term liquidity shocks. Hence, they facilitate short-term liquidity management and the steering of short-term momey market rate to the central bank's policy rate.
} 
timing and size of its money market operations. In turn, better-informed money market operations effectively steer liquidity in the system to its optimal level and set up the technical conditions for a smooth functioning of the market. The central bank can therefore be less concerned about interest rate volatility that may arise due to forecasting errors and can set a wider interest spread between its deposit standing facility and its lending standing facility, a desirable feature to encourage market trading.

The central bank must ensure that the structure of its interest rates is conducive to interbank trading. In particular, the interest rates applied to various instruments must be internally consistent, and the spread between the interest rate applied to liquidity-providing operations and the rate applied to liquidity-absorbing operations must be wide enough to provide adequate incentives for banks to deal with one another in the interbank market. The stylized structure of central bank interest rates provided in Table 4 allows for a combination of a refinance standing facility and a deposit standing facility that creates room (or a corridor) for market participants to deal with one another first, and with the central bank as a last resort.

Table 4. Stylized Structure of Interest Rates

\begin{tabular}{clc}
\hline Level & \multicolumn{1}{c}{ Interest rates } \\
\hline Highest & Lending interest rates in commercial banks \\
& Central bank's refinancing standing facility rate \\
& Central banks' open market operations rate \\
& Central bank's deposit standing facility rate \\
Lowest & Remuneration of retail deposits in commercial banks
\end{tabular}

Source: based on Laurens (2005).

\section{B. Strengthening China's Strategic Framework}

\section{Possible anchoring strategies}

Three strategies could be considered for China to provide a nominal anchor as it moves to a flexible exchange rate regime: inflation targeting, monetary targeting or an eclectic framework which involves the monitoring of a broad range of monetary and economic indicators. ${ }^{46}$

Regarding monetary targeting, although in the long run there seems to be a recognizable link between money growth and inflation, the current low inflation environment in China, makes it difficult for policy makers to manage inflation based on money targets given that short-run

\footnotetext{
${ }^{46}$ See Appendix IV for an overview of an anchoring strategy based on the monitoring of financial and monetary indicators as intermediate targets.
} 
instabilities may add some noise in the decision-making progress. Therefore, a money target would not constitute a good stand-alone nominal anchor.

Regarding inflation targeting (IT), notwithstanding China's persistently low inflation rate and PBC's interest in moving to IT over time, the adoption of a full-fledged IT framework does not seem a viable option for the foreseeable future. The lack of central bank operational independence and weaknesses in the production of reliable medium-term inflation forecast are among a number of significant impediments to adopting IT. Furthermore, adopting inflation targeting would imply greater reliance on interest rates in the conduct of monetary policy, and issue still widely discussed in China. ${ }^{47}$

Therefore, the monetary strategy most suitable to China at this juncture appears to be an eclectic monetary policy framework, with the growth in money supply and bank credit being as intermediate guidelines ${ }^{48}$ for the determination of short-term interest rates. Indeed, we found that money growth and inflation tend to be highly correlated in the long run, suggesting that intermediate guidelines for monetary aggregates can still play a useful operational role to stabilize inflation, and provide timely evidence to help assess the sustainability of an asset price boom.

However, money and credit aggregates cannot be relied upon as the only nominal anchor given that changes in economic structure and financial markets may entail some inconsistencies between the rate of money growth and a stable rate of inflation. Therefore, in deciding on the most appropriate monetary policy stance, the PBC will need to consider developments in a number of other variables because the monetary aggregates cannot be the only indicators of future inflation due to structural changes in the economy. ${ }^{49}$

As discussed in Appendix IV, this approach recognizes the uncertainty and complexity involved in forecasting the final objective and does not rely on a single variable or model. The variety of indicators typically includes financial indicators and real sector indicators that can help predict future inflation. This approach requires putting a lot of emphasis on research, modeling, internal communication and discussion. It makes necessary regular meetings to discuss conjectural events, preparation of material to inform policy makers and

\footnotetext{
${ }^{47}$ While some advocate greater reliance on interest rates signals in view of its benefits for financial market development and the allocation of funds, others emphasize the risks, in particular its implications for the provision of bank credit to the financially weak fraction of the corporate sector (i.e., state-owned enterprises).

${ }^{48}$ Based on the level of confidence that empirical evidence provides, the role of money can range from being used to define quantitative targets, to being used to supplement the short-term risks to price stability with medium-term risks, as is the practice at the ECB (see Appendix V for a review of the ECB approach and Mishkin (2000) for a review of the experience of selected industrialized countries with monetary targeting).

49 See also Goodfriend and Prasad, 2006.
} 
elaboration and communication of forecasts and reports. The central bank becomes a sophisticated machinery of information collection and analysis. ${ }^{50}$

\section{The case for using the interest rate as the operating procedure}

In view of the weakening of the relationship between money (and credit) and inflation, following Walsh (2003) we now test the desirability of relying on interest rates as the operating procedure for monetary policy. The basic issue is whether the central bank should keep the interest rate constant or should hold a monetary quantity constant, thus allowing interest rates to move, to be better positioned to achieve its inflation objective.

In most cases, the goal of monetary policy is to select an instrument of monetary policy to minimize the variance of output deviations. Hence following Walsh (2003) we state a simple variant of a basic IS-LM model in log terms:

$$
\begin{aligned}
& \text { Min } E\left(y_{t}^{2}\right) \\
& y_{t}=B_{1} r_{t}+u_{t} \\
& m_{t}=y_{t}+B_{2} r_{t}+e_{t}
\end{aligned}
$$

where represents output and $y=0$ is the economy equilibrium level of the output gap when there are no shocks; $r_{t}$ is the nominal rate of interest; ${ }^{51} m_{t}$ represents a nominal monetary aggregate, and $u_{t}$ and $e_{t}$ are stationary uncorrelated stochastic process. ${ }^{52}$ From (6) we obtain:

$$
r_{t}=\frac{m_{t}-y_{t}-e_{t}}{B_{2}}
$$

Now plugging (5) in (7) we obtain,

$$
y_{t}=B_{1}\left[\frac{m_{t}-y_{t}-e_{t}}{B_{2}}\right]+u_{t}
$$

Solving for $y_{t}$,

\footnotetext{
${ }^{50}$ Within such a strategic framework, the PBC may announce a long run inflation goal (making it clear that this is not a move to an IT framework) as a priority for monetary policy to help tie down inflation expectations (see also Goodfriend and Prasad, 2006).

${ }^{51}$ We use the benchmark rate for RMB denominated deposit rate.

${ }^{52}$ The level has been normalized to equal 1 . Hence the log of the price level is zero $(p=0)$.
} 
$y_{t}=\frac{B_{1}}{B_{2}-B_{1}} m_{t}-\frac{B_{1}}{B_{2}-B_{1}} e_{t}+\frac{B_{2}}{B_{2}-B_{1}} u_{t}$

The objective function then becomes,

$E\left[y_{t}\right]^{2}=\frac{-B_{1}^{2} \sigma_{e}^{2}+B_{2} \sigma_{u}^{2}}{\left(B_{1}-B_{2}\right)^{2}}$

When the interest rate is used as the policy instrument, the money market is in equilibrium because the money stock adjusts endogenously to be at the same level as money demand. Therefore, setting the interest rate such as $E(y)=0$ we get,

$E_{i}\left(y_{t}\right)^{2}=\sigma_{u}^{2}$

Then, the criteria to choose the interest rate as operating procedure (instead of a moneysupply operating procedure) is the following,

$E_{i}\left(y_{t}\right)^{2}<\sigma_{u}^{2}$

or

$\frac{-B_{1}^{2} \sigma_{e}^{2}+B_{2} \sigma_{u}^{2}}{\left(B_{1}-B_{2}\right)^{2}}<\sigma_{u}^{2}$

This is equivalent to the following condition:

$\sigma_{e}^{2}>\frac{\left(B_{1}-2 B_{2}\right)}{B_{1}} \sigma_{u}^{2}$

or

$\sigma_{e}^{2}>\left[1-\frac{\left(2 B_{2}\right)}{B_{1}}\right] \sigma_{u}^{2}$

Simply put, the interest rate might be chosen as an operating target (i) whenever the variance of the money demand disturbances is larger, (ii) the LM is steeper, and (iii) the IS curve is flatter. In other words, the interest rate would respond as a reliable operating target when money demand is perceived as unstable and difficult to predict over short-time periods, when changes in interest rates convey significant influence on output (thus inducing greater output stability), and when changes in interest rates are not significant enough to stabilize output through the money market. Applying this setup to China, we get results (see below) which 
imply that an interest rate would be desirable as the operating target for monetary policy conduct in China.

$\sigma_{e}^{2}>\left[1-\frac{\left(2 B_{2}\right)}{B_{1}}\right] \sigma_{u}^{2}$

$4.3830<37.3303$

Hence, monetary policy would benefit from giving the PBC full discretion to make interest changes, so that it can start using a policy interest rate more actively.

\section{Strengthening China's Operational Framework}

The multiplicity of PBC objectives makes difficult reliance on an operational framework fully consistent with modern central banking. In particular, the PBC is concerned with maintaining the profitability of the state-owned banks as well as creating an environment for the development of market-oriented loans and deposits pricing mechanisms, hence the maintenance of a mechanism to monitor banks' margins. Consequently, the PBC lacks a well-defined operational target. The PBC is also concerned with optimizing the allocation of funds, hence reliance on window guidance to improve the structure of banks' loan portfolios, in particular requiring banks to differentiate credit policies to different sectors and improve their credit services to SMEs. Finally, in day-to-day conduct of monetary policy, the PBC is faced with the current structural excess liquidity in the banking system..$^{53}$ The following paragraphs elaborate on measures to address some of the obstacles to a migration to an operational framework centered on interest rates.

\section{Operational target of monetary policy}

The PBC should consider defining a short term interest rate as its operational target. The exact specification of the operational target should be such as to avoid strictly committing the PBC to control the short term interest rate very precisely. The PBC could announce that its short-term bills rate (either a fixed rate or a maximum bid rate) would communicate the stance of monetary policy, and explain that it would normally expect short term interbank rates to remain on average close to this policy rate. Alternatively, it could declare its shortterm bills rate to be its operational target, mentioning however that this does not mean that this rate could not fluctuate to some extent around the pre-announced target level. Overall, the first approach seems to be slightly preferable, as it avoids strict commitment by the PBC.

\footnotetext{
53 Another challenge, outside of the scope of this paper, has to do with the lack of a an operational framework with regard to the official policy of keeping the RMB exchange rate stable at an adaptive and equilibrium level.
} 


\section{Banks’ margins monitoring}

Shifting to a short-term money market rate as the operational target of monetary policy would imply lifting the interest rate controls on banks' deposit and lending operations. Such a measure would allow a market-based allocation of savings, therefore potentially enhancing the effectiveness of financial intermediation and of monetary policy. Removing benchmark lending and deposit rates would also allow the market to determine the shape of the yield curve, which is a key feature of modern central banking. Should concerns about the profitability of banks remain strong, the PBC could rely on a mechanism to monitor banks' margins for their loan portfolios (Box 3).

Box 3. Monitoring Banks’ Margins: Country Examples

A variety of mechanisms may be used to prevent oligopolistic behavior, and thus ensure transparency and fair competition, in the market. In Thailand, at some point the central bank and the banks agreed to establish the minimum retail rate as a reference lending rate for small but good-quality borrowers. The minimum retail rate included four components: the average cost of funds, the operating costs, a tax levied on financial transactions, and a profit margin. In Malaysia, all rates used to be anchored to each bank's declared base lending rate, which was based on a bank's costs of funds. During a period, the base lending rate was subject to central bank's guidelines. In 1991, it was freed from administrative control, allowing it to become akin to the prime rate in use in some countries.

Source: Mehran, Laurens, and Quintyn (1995).

\section{Excess reserves}

Bringing excess reserves to a level consistent with banks' minimum settlement balances would facilitate reliance on a short-term interest rate as the operational target of monetary policy. Lowering, and eventually removing the remuneration of the excess reserves, so as to be consistent with the practice in developed countries, while not absorbing the reserves in excess of normal working balances may lead to an expansion of bank loans. ${ }^{54}$ Therefore, a shift to a short-term interest rate as the operational target for monetary policy should be introduced only when banks' reserves are brought down to a level consistent with the banks' minimum working balances. ${ }^{55}$ The objective would be to ensure stable liquidity conditions so that the PBC can effectively steer its operational target, thereby contributing to more efficient transmission of monetary policy.

\section{Liquidity absorbing versus liquidity providing monetary operations}

Consideration could also be given to conducting monetary policy from a structural liquidity deficit position. Reliance on administrative measures for monetary policy conduct, including window guidance and the forced placement of PBC bills, suggests that the PBC is not confident that liquidity-absorbing market-based monetary operations would allow achieving

\footnotetext{
${ }^{54}$ There is anecdotal evidence that the 2005 reduction of the ERR resulted in high credit growth.

${ }^{55}$ Another option would be to increase the level of remuneration of excess reserves to a market level if the instrument is to be used to mop up excess liquidity on a permanent basis.
} 
the overall policy objectives. Indeed, in shallow markets, reliance on market-based monetary operations can be facilitated when the central bank conducts the bulk of its monetary interventions in the form of liquidity-providing operations. This reduces the scope for collusion or overshooting because the banking system has no choice but to borrow from the central bank. Therefore, in the short-term, the central bank can achieve a particular liquidity objective and still control the interest rate at which it lends to the system, for instance, by using a volume tender. This is not the case when the central bank conducts the bulk of its monetary interventions in the form of liquidity-absorbing operations. In that case, banks have a choice between lending to the central bank or to their customers. Hence, if the central bank wants to mop up a specific amount of liquidity it needs to rely on an interest rate tender (i.e., banks bid for quantity and price), therefore, there is a risk that interest rates may overshoot.

Central banks around the world have used a variety of instruments to create a structural liquidity shortage, including mandatory banks' deposits or forced placement of central bank bills (Box 4). Those central bank assets have been remunerated at market rates in order to limit the distortionary effects of such measures. The PBC has also relied on reserve requirements and, at times, forced placement of PBC bills, to withdraw some of the excess liquidity from the system. However, reserve requirements should be remunerated at a rate in line with short-term money market rates to limit their distortionary effect. While the forced placement of PBC bills may be acceptable under current circumstances, the arrangements should create a level playing field between all financial institutions (i.e., forced placement

Box 4. Cross-Country Experiences with Dealing with a Liquidity Surplus

In Mexico, the central bank has been using mandatory remunerated deposits to attain a creditor position in the money market. Deposits are distributed based on banks' liabilities and they receive a market-based remuneration.

During the 1970-80s, the Bank of Spain (BDE) used non-remunerated reserve requirements and forced deposits remunerated at below-market rates to create an operational liquidity deficit. After 1990, nonremunerated required reserves were gradually substituted with mandatory holdings of BDE bonds. In the 1980s, the central bank of the Netherlands (DNB) used mandatory market-rate-remunerated deposits and DNB bills to create an operational liquidity deficit. In 1994, the DNB started issuing 6month certificates of deposit at market rates.

Source: Laurens (2005) should follow a pre-announced rule), and the remuneration of PBC bills should be in line with market rates.

A move to a structural liquidity shortage could be instigated at any time. However, it would be best implemented in combination with a gradual exit strategy of the PBC from the foreign exchange market. Indeed, since the growth of banks' reserves is for the most part attributable to international reserves accumulation, such timing would help reduce the need to expand continually the magnitude of the financial operations aimed at creating a liquidity shortage.

\section{CONCLUSIONS}

Our review of progress made in developing modern central banking frameworks shows that China has achieved a level of financial liberalization which places the monetary authorities in 
a strong position to enter the final stage of central bank modernization toward full reliance on market-forces for monetary policy implementation. The modernization of the central bank has been a gradual and uninterrupted process. Such an approach has obviated the need for radical changes along the way, and the PBC now relies on monetary frameworks and instruments comparable to those used by central banks in the most advanced countries. Furthermore, even if banks' operations remain subject to interest rate controls, several avenues are in place which allow some corporations to operate in a free market environment.

However, the effectiveness of the current framework is likely to diminish over time as the sophistication of the economy increases. We find that when inflation is low, the informative role of monetary aggregates falls perhaps due to an unstable multiplier: at lower rates of inflation the association between money and inflation looses its strength. Therefore, money cannot be the only intermediate target for monetary policy. We also find that the adoption of an inflation targeting framework is not a viable option for China at this juncture.

Therefore, we argue that the most suitable monetary strategy for China would be an eclectic monetary policy framework, whereby the growth in money supply and bank credit extension are used as intermediate guidelines for the determination of short-term interest rates. In addition, in deciding on the most appropriate monetary policy stance, developments in a number of other variables need to be taken into consideration, because the monetary aggregates are loosing some of their usefulness as indicators of future inflation due to structural changes in the economy.

Furthermore, we find empirical evidence supporting a greater role for interest rates in the conduct of monetary policy. Adopting interest rates as the operating target for monetary policy in China would help increase the effectiveness of China's monetary policy, as well as a more efficient allocation of financial resources and savings, therefore contributing also to better risks management in the financial sector.

In order to pave the way for greater reliance on a policy interest rate as the operating target for monetary policy, we argue that the PBC should adopt a short-term interest rate as its operational target. The PBC should also reduce further banks' excess reserves balances, with a view to bring them to levels in line with banks' minimum working balances. This is a condition for the PBC to manage liquidity in a conventional manner. The aim would be to provide banks with incentives to borrow from each other in the interbank market and then use a short-term money market rate as a policy signal. The PBC could supplement its policy rate with a corridor for short-term money market interest rates.

Finally we identify policy measures to address some of the concerns of the authorities regarding the potential disruptions that a move to fully-fledged market-based monetary policy may entail. The current limits to banks' deposit and lending rates could be replaced by a mechanism to monitor banks' margins for their loan portfolio as a whole, rather than for each individual loan. Consideration could also be given to conducting monetary policy from a structural liquidity deficit position, including by using transparent rules-based instruments to induce banks to borrow from the central bank and, hence, create a liquidity shortage. 
However, an important prerequisite for shifting to fully-fledged market-based monetary policy conduct would be to grant the PBC full discretion to make interest rate changes so that it can start using its policy interest rate more actively. Such a move appears the most urgent policy measure at this juncture, and we argue that the PBC has in place the monetary frameworks and instruments to rely fully on market-based monetary policy. 


\section{Appendix I. Why the PBC Should Rely on Market-Based Monetary Policy}

We summarize in four arguments why a move to market-based monetary policy implementation has become a pressing issue for China.

\section{Empirical evidence and international experience supports the move}

- $\quad$ The quantity-based monetary framework is loosing its effectiveness. In particular, money cannot provide the sole guide for monetary policy implementation

- $\quad$ Empirical evidence and modern central banking practices support making a shortterm interest rate the operational target of monetary policy

\section{Administrative instruments involve growing inefficiencies}

- They delay the "marketization" of the financial sector

- $\quad$ They hold back the efficient allocation of savings

- $\quad$ They loose effectiveness with the opening of the financial sector

\section{A minimum set of initial conditions is in place}

- $\quad$ Nation-wide foreign exchange and money markets are in place

- $\quad$ Interest rates have been liberalized, except for a maximum deposit rates and minimum lending rates

- $\quad$ The PBC has the infrastructure and skills to conduct open market operations

Measures can be implemented to address remaining concerns

- A mechanism to monitor banks' margins for their loan portfolios could replace the current maximum deposit rates and minimum lending rates

- $\quad$ The potential for interest rates overshooting could be reduced by conducting monetary policy from a structural liquidity deficit position 


\section{Appendix II. Monetary Policy with Open Capital Account and Large Capital Inflows}

The inability to simultaneously maintain fixed exchange rates, an independent monetary policy and unrestricted capital flows lead to the difficulties in trying to implement a monetary policy with multiple targets. When capital inflows are permitted and become substantial, they can pose a serious challenge to monetary policy. If an exchange rate target is given priority, then price stability might be endangered (in addition to other implications of an inflexible exchange rate); if the exchange rate is allowed to appreciate, then there are implications for competitiveness and economic activity.

As shown in the table below, there are a number of policy responses available. Most countries have responded with a combination of steps as depicted in the table below, including greater exchange rate flexibility.

Table A1.1. Policy Responses to Large Capital Inflows

\begin{tabular}{|c|c|c|c|c|c|c|c|c|}
\hline & $\begin{array}{l}\text { Tighter } \\
\text { Fiscal } \\
\text { Policy } \\
\end{array}$ & $\begin{array}{l}\text { Revaluation/ } \\
\text { Appreciation }\end{array}$ & $\begin{array}{c}\text { Sterilized } \\
\text { interv. }\end{array}$ & $\begin{array}{l}\text { Exchange } \\
\text { rate } \\
\text { Flexibility }\end{array}$ & $\begin{array}{l}\text { Policy Rate } \\
\text { Reduction }\end{array}$ & $\begin{array}{l}\text { Liberalize } \\
\text { Capital } \\
\text { Outflows }\end{array}$ & $\begin{array}{l}\text { Control } \\
\text { Capital } \\
\text { Inflows }\end{array}$ & $\begin{array}{c}\text { Banking } \\
\text { Sector } \\
\text { Reforms }\end{array}$ \\
\hline $\begin{array}{l}\text { Bulgaria (1997- } \\
2000)\end{array}$ & Yes & No & No & No (i) & No & Yes & No & Yes \\
\hline Chile (1991-98) & Yes & Yes & Yes & Yes & n.a & Yes & Yes & Yes \\
\hline $\begin{array}{l}\text { Croatia (1993- } \\
\text { 2001) }\end{array}$ & Yes & No & Yes (a) & Yes & No & No & Yes (b) & Yes \\
\hline Czech R. & No & No & Yes & Yes & Yes & Yes & No & No \\
\hline $\begin{array}{l}\text { Hungary (1995- } \\
\text { 96) }\end{array}$ & Yes & No & Yes & Yes & Yes & Yes & No & Yes \\
\hline $\begin{array}{l}\text { Israel (late 80s- } \\
\text { 2004) }\end{array}$ & Yes (c) & Yes & Yes & Yes & n.a & Yes & Yes (d) & Yes \\
\hline $\begin{array}{l}\text { Poland (1995- } \\
\text { 2004) }\end{array}$ & Yes (e) & Yes & Yes & Yes & Yes & Yes (f) & Yes (g) & Yes (h) \\
\hline $\begin{array}{l}\text { Romania } \\
\text { (2000s) }\end{array}$ & Yes & Yes & Yes & Yes & Yes & No & Yes (d) & Yes \\
\hline
\end{tabular}

Notes: (a) Limited; (b) Temporary; (c) At times; (d) Moderating the phase of capital inflow liberalization; (e) Until 2000. Since 2001 deterioration of public deficit; (f) Implemented because of EU and OECD considerations, however, delayed as much as possible;(g) Careful liberalization sequenced: FDIs $\Rightarrow$ portfolio long-term inflows $\Rightarrow$ ER floating $\Rightarrow$ liberalization of short-term capital movements; (h) Further privatization of the banking sector in the second half of the 1990s mostly based on FDI inflows; (i) Bulgaria operates a currency board arrangement, which does not allow flexibility of the exchange rate.

The response should be appropriate to the causes and nature of the capital inflow. Coordination and sequencing of policy steps, as well as maintaining policy flexibility is vital. Establishing appropriate initial conditions and making suitable preparations is key. In this context, fiscal adjustment, structural reforms to improve external competitiveness, credible monetary policy and effective monetary operations, a stable financial system with strong risk management practices, and well developed financial markets can mitigate the risks posed by large capital inflows. 
Specific policy responses include: monetary easing; sterilized FX intervention; exchange rate adjustment and increased exchange rate flexibility. In addition, the pace and sequencing of capital account liberalization can be adjusted in response to developments. Administrative controls and measures have also been used. Each of these responses has advantages, costs and limitations, so the policy response should be tailored to the specific situation. In general terms, country experiences show that the time to "cope" with capital inflows is before they become a problem. In this regard, foreign exchange intervention can buy time, but is costly and limited in effectiveness. In addition, administrative controls are costly in both the short and long term, and their effectiveness is questionable. 


\section{Appendix III. Modeling Money Demand in China}

Money demand equations are adequate instruments to examine the long-run relationship between money and prices. In particular, money demand becomes an important analytical tool, when monetary policy is not geared towards ensuring the clearing of the money market through the use of the nominal interest rate. According to our findings, the existence of a stable long-run relationship (cointegration) between monetary aggregate M2 and its determinants cannot be rejected. Consequently, M2 exhibits a stable long-run relationship with key macroeconomic variables such as inflation, real GDP, and interest rates. The demand for nominal M2 adjusts to price movements in the long-run, thus leaving unchanged the desired level of real balances (there exists long-run homogeneity between money and prices).

The following long-run specification for the demand for money balances is estimated and supported by the data:

$$
(m-p)_{t}=c+\beta_{1} y_{t}-\beta_{2} i_{t}-\beta_{3} \pi_{t}
$$

where $m, p, y$ and $\pi$ denote, respectively, M2, the price level, real GDP and inflation. All variables are in logarithms with the exception of interest rates and they have been seasonally adjusted. Also, all variables were taken from the International Financial Statistics with the exception of GDP that belongs to a recent revision provided by the Chinese authorities. It is expected that real money demand is positively related to the level of real income and negatively related to the rate of interest and inflation

The least squares regression for the period 1994 (first Quarter) to 2005 (fourth quarter) provides the following results:

\begin{tabular}{lcccc}
\hline Variable & Coefficient & Std. Error & t-Statistic & Prob. \\
\hline C & -5.479164 & 0.309649 & -17.69477 & 0.0000 \\
GDP & 1.774893 & 0.039214 & 45.26159 & 0.0000 \\
$i$ & -0.003918 & 0.004104 & -0.954570 & 0.3457 \\
$\pi$ & -0.004666 & 0.001163 & -4.013068 & 0.0003 \\
AR(1) & 0.268082 & 0.163178 & 1.642876 & 0.1084 \\
R-squared & 0.998367 & Mean dependent var & 7.824495 \\
Adjusted R-squared & 0.998199 & S.D. dependent var & 0.518340 \\
S.E. of regression & 0.021995 & Akaike info criterion & -4.689362 \\
Sum squared resid & 0.018867 & Schwarz criterion & -4.486613 \\
Log likelihood & 108.1660 & F-statistic & 5960.479 \\
Durbin-Watson stat & 1.960559 & Prob(F-statistic) & 0.000000 \\
\hline
\end{tabular}

The estimated short-run demand function shows that all variables have the correct sign and they are statistically significant. In particular, the coefficients associated with the interest rate and inflation are null while the associated impact of economic activity is large. 
The empirical results support the stability of money demand. ${ }^{56}$ The maximal eigenvalue and trace eigenvalue statistics - with a degrees of freedom adjustment ( $\lambda_{\max }^{a}$ and $\lambda_{\text {trace }}^{a}$ )- reject the null hypothesis of no cointegration in favor of one, and possibly two cointegrating relationships as presented in the following table:

\begin{tabular}{ccccc}
\hline $\begin{array}{c}\text { Hypothesized } \\
\text { No. of CE(s) }\end{array}$ & Eigenvalue & $\begin{array}{c}\text { Trace } \\
\text { Statistic }\end{array}$ & $\begin{array}{c}0.05 \\
\text { Critical Value }\end{array}$ & Prob. $^{*}$ \\
\hline 0 & 0.580080 & 73.67913 & 47.85613 & 0.0000 \\
1 & 0.351435 & 36.36844 & 29.79707 & 0.0076 \\
2 & 0.338191 & 17.74975 & 15.49471 & 0.0225 \\
3 & $6.59 \mathrm{E}-06$ & 0.000284 & 3.841466 & 0.9886 \\
\hline
\end{tabular}

MacKinnon-Haug-Michelis (1999) p-values

Cointegration analysis tests for the existence of a set of coefficients, namely the cointegrating vector, that defines a linear combination of M2, income, interest rates and inflation which is stable over time. ${ }^{57}$ Accordingly, these findings suggest that the residuals of the money demand equation are stationary meaning that M2, income, interest rates and inflation are cointegrated.

The next table shows the estimation results (normalized cointegration coefficients).

\begin{tabular}{lcc}
\hline & Dependent Variable: Real Money Balances (M2) \\
\hline Variables & Estimate & Std. Error \\
Real GDP & 1.84 & 0.035 \\
Interest rate & -0.01 & 0.003 \\
Inflation & 0.01 & 0.001 \\
\hline
\end{tabular}

Overall, the models suggest that the growth in real monetary aggregates (M2) since 1994 was primarily driven by a significant increase in real output. While the decline in inflation and interest rates have contributed to increasing money demand, their effects were relatively small.

\footnotetext{
56 The ADF tests (not shown here) cannot reject the null hypothesis of the presence of a unit root in all series suggesting the existence of a stochastic trend thus implying that they are stationary in first differences.

${ }^{57}$ If the variables involved are not cointegrated, then the differences among them could become larger as time goes by, without a tendency to return to a stable path together.
} 


\section{Appendix IV. Monitoring Financial and Monetary Indicators as Intermediate Targets}

Which variables a central bank should monitor depends crucially on the instruments used for policy implementation, the final objectives of monetary policy and the transmission mechanisms from instruments to objectives. The Figure below shows a general case in which the final objective is inflation, there is a well identified monetary policy instrument (MPI). The transmission mechanism goes from the instrument to financial markets affecting the real sector and costs and finally to inflation.

Figure A3.1 Instruments, objectives and transmission mechanisms

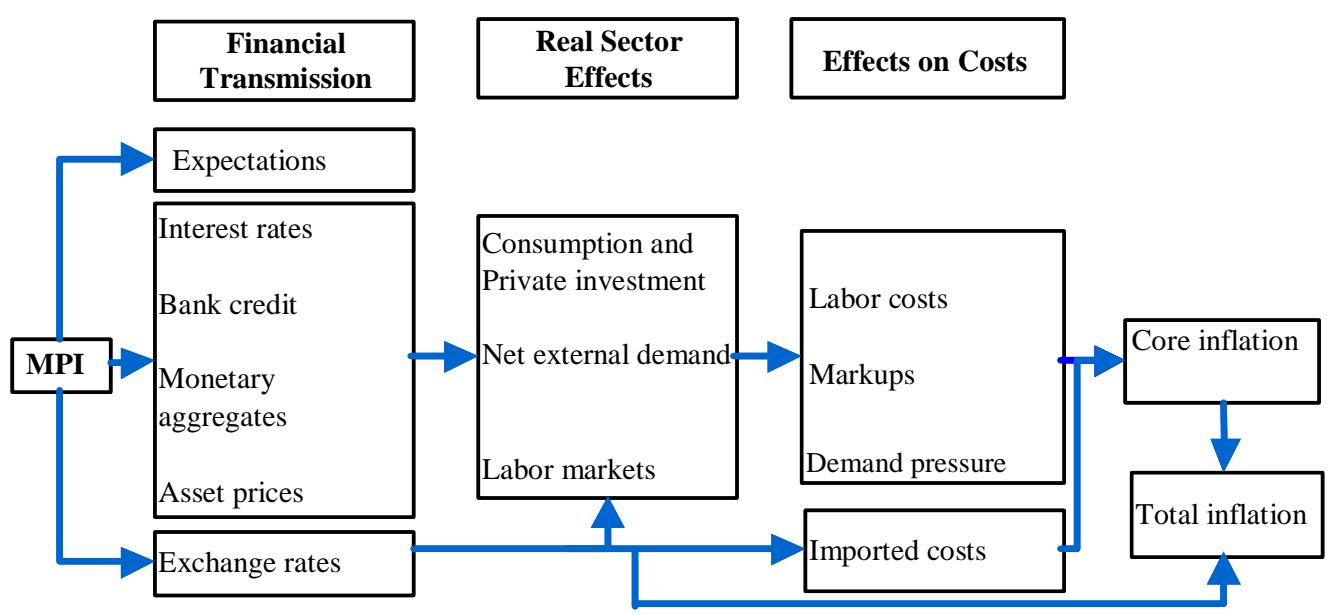

One approach would be to focus only on monetary aggregates. For such an approach to be effective, the central bank needs to identify a monetary aggregate which is a stable and reliable predictor of inflation. Another approach would be to focus on a more broad definition of financial conditions, such as monetary condition indexes (MCIs), that take into account not only money but also interest rates and the exchange rate.

Nevertheless, there is no good reason to restrict monitoring only to a narrow set of indicators. A more eclectic approach, in particular adopted by inflation targeters, is to follow a large set of variables. This approach recognizes the uncertainty and complexity involved in forecasting the final objective and does not rely on a single variable or model. The variety of indicators typically includes financial indicators (interest rates, yield curve, money growth, credit growth, exchange rates and other relevant asset prices and quantities), real sector indicators (internal demand, current account, production, labor markets), labor costs and markups indicators and other indicators that can help predict future inflation such as core inflation measures or surveys. This approach requires putting a lot of emphasis on research, modeling, internal communication and discussion. It makes necessary regular meetings to discuss conjectural events, preparation of material to inform policy makers and elaboration and communication of forecasts and reports. The central bank becomes a sophisticated machinery of information collection and analysis. 


\section{Appendix V. The Role of Money and Asset Prices in the ECB Monetary Strategy}

The primary objective of the European Central Bank's (ECB) is price stability. ${ }^{58}$ Monetary policy decisions are based on two pillars, economic analysis (focusing on shorter-term price movements largely influenced by interplay of supply and demand in goods, services and factor markets) and monetary analysis (focusing on longer-term price trends closely linked to underlying trends in the money stock). A framework for internal decision-making aims at providing the Governing Council with all relevant information and analysis required to take appropriate policy decisions. At the same time, external communication provides the public with a clear, consistent framework to present and explain policy decisions and the rationale behind decisions.

The ECB has decided to give importance to monetary analysis. The ECB does not have a monetary target, but within this monetary pillar there is a specific focus on the analysis of the components and counterparts of M3. This decision was made in recognition of the fact that monetary growth and inflation are closely related in the medium to long run. This relationship provides monetary policy with a nominal anchor beyond the horizons conventionally adopted to construct inflation forecasts. Therefore, the role of monetary analysis in the strategy also underpins the medium-term orientation. Over time monetary analysis has been deepened and broadened. ${ }^{59}$ Macroeconomic projections play an important but not an all-encompassing role. There are other variables/indicators to include, such as: a broad range of price and cost indicators; aggregate demand and its components; labor market conditions (including wage negotiations); fiscal developments (including administered prices, taxes); financial markets conditions (yield curve; asset prices; exchange rate); and private sector expectations (inflation; real growth, etc.) based on financial market prices and surveys. The table below shows how longer-term movements in monetary growth lead longer-term movements in HICP inflation. The lead time is of relevance for policy decisions, given likely lags in transmission.

In assessing the outlook for future price stability, the short to medium-term indications coming from economic analysis are cross-checked with the medium to long-term perspective coming from monetary analysis.

- Monetary developments contain information about the state of the economy whichregardless of whether money plays an active role in the transmission mechanism of monetary policy—should be integrated into the policy making process.

- $\quad$ Furthermore, monetary and credit aggregates can provide timely evidence to help assess the sustainability of an asset price boom. Empirical research has shown that

\footnotetext{
${ }^{58}$ Based on ECB (2003), and (2004); Issing (2003), and Masuch, Nicoletti-Altimari, Pill and Rostagno (2003).

${ }^{59}$ ECB Monthly Bulletin, October 2004: "Monetary Analysis in Real Time”.
} 
asset price bubbles which end up in economic and financial distress were often preceded by excessive monetary developments.

Table A4.1. Correlation Between Long-Term Trends in Monetary and Inflation, 1986-2004

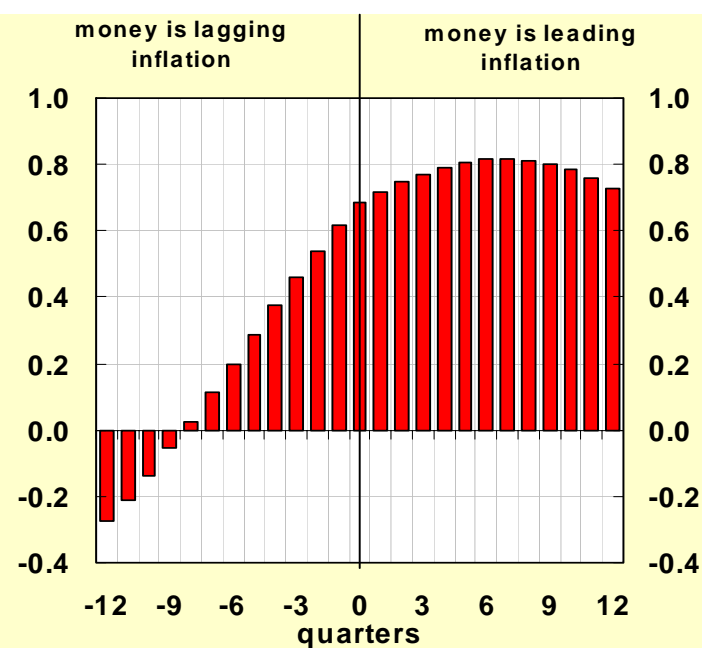

Source: Based on Bruggeman, et al. (2005).

The ECB does not target asset prices. It is considered that monetary policy should take asset prices into account to the extent that it supports price stability over the medium term. Asset prices are monitored as they a) play a key role in the monetary policy transmission process; b) help to identify the nature of shocks and c) reveal information about private sector expectations.

The ECB monitors asset price dynamics closely because of the potentially very high costs for price stability and for the economy as a whole that are associated with strong appreciations and subsequent rapid reversals in asset prices.

Under certain circumstances, a policy of "leaning against the wind" of an incipient identified bubble might be considered. The central bank would then adopt a tighter policy stance in the face of an inflating asset market than it would otherwise allow if confronted with a similar macroeconomic outlook under more normal market conditions. Hence, and given uncertainty about the appropriate policy stance, a central bank would err on the side of caution in trying to avoid feeding the bubble with an accommodative policy. It would thus possibly tolerate a certain deviation from its price stability objective in the shorter term in exchange for enhanced prospects of preserving stability in the medium to long term.

Monetary analysis can contribute to assessing the extent to which excess creation of liquidity and over-extension of credit may be a driving force behind excessively valued assets. Detecting and understanding this link helps to form an opinion on whether an observed movement in monetary aggregates and their counterparts might already reflect an overly expansionary monetary policy which contributes to inflating an asset price bubble. 


\section{REFERENCES}

Barnett, Steven, 2004, "Banking Sector Developments,” in “China’s Growth and Integration into the World Economy,” IMF Occasional Paper No. 232, edited by Esward Prasad (Washington: International Monetary Fund).

Bindseil, Ullrich, 2004, "The Operational Target of Monetary Policy and the Rise and Fall of the Reserve Position Doctrine,” ECB Working Paper No. 372 (Frankfrut am Main: European Central Bank).

Bruggeman, Annick, Gonzalo Camba-Méndez, Björn Fischer and João Sousa, 2005, "Structural filters for monetary analysis: the inflationary movements of money in the euro area,” European Central Bank Working Paper No. 470.

Boyreau-Debray, Genevieve and Shang-Jin Wei, 2004, “Can China Grow Faster? A Diagnosis of the Fragmentation of its Capital Market,” IMF Working Paper No.04/76.

European Central Bank, 2003, “The Outcome of the ECB's Evaluation of its Monetary Policy Strategy,” Monthly Bulletin, June, pp. 79-92 (Frankfurt am Main: European Central Bank).

_ 2004, “The Monetary Policy of the ECB,” (Frankfurt am Main: European Central Bank).

— 2004, “Monetary Analysis in Real Time,” Monthly Bulletin, October, pp. 43-66 (Frankfurt am Main: European Central Bank).

— 2005, “Asset Prices and Monetary Policy”, Monthly Bulletin, April, pp. 47-60 (Frankfurt am Main: European Central Bank).

Estrella, A. and Mishkin, F., 1997, "Is there a role for monetary aggregates in the conduct of monetary policy?” Journal of Monetary Economics, Vol 40, pp. 279-304.

Freedman, Charles, 2006, "From Monetary Targeting to Inflation Targeting: The Change in the Role of Money in the Conduct of Monetary Policy," unpublished.

Geiger, Michael, 2006, “Monetary Policy in China (1994-2004), Targets, Instruments and their Effectiveness,” Würzbug Economic Papers No. 68.

Goodfriend, Marvin and Eswar Prasad, 2006, “A Framework for Independent Monetary Policy in China,” IMF Working Paper No. 06/111 (Washington: International Monetary Fund).

Green, Stephen, 2005, “Making Monetary Policy Work in China: A Report from the Money Market Front Line.” 
— 2006, “On the Ground, Asia. Real Estate Agent: Beijing’s New Role” Standard Chartered, June.

_ 2006, "On the Ground, Asia. The PBoC's Carrots and Sticks" Standard Chartered, June 21, 2006.

_ 2006, "On the Ground, Asia. Sterilization: The PBoC Finally Gets Serious" Standard Chartered, July 11, 2006.

Green, Stephen and Jason Chang, 2006, “On the Ground, Asia. The PBC’s Big Money Problem," Standard Chartered, June.

HSBC, 2005, "The Great Migration: How China's 200 million new workers will change the economy forever,” HSBC Global Research.

International Monetary Fund and World Bank, 2001, “Developing Government Bond Markets: A Handbook."

Issing, O., 2003, “The Evaluation of the Strategy,” opening remarks at the ECB Watchers Conference, Frankfurt, 11 July.

Issing, O., 2004, "Financial Integration, Asset Prices and Monetary Policy,” speech for the symposium concluding two years of the ECB-CFS Research Network on Capital Markets and Financial Integration in Europe, May 10.

Karacadag, Cem, 2003, “Financial System Soundness and Reform,” in China: Competing in the Global Economy, ed. by Wanda Tseng and Markus Rodlauer (Washington: International Monetary Fund).

Kato, Takatoshi, 2006, “IMF: From a Firefighter to A Doctor,” interview with People's Daily (June 30, 2006).

Lardy, Nicholas R., 2005, “Exchange Rate and Monetary Policy in China,” CATO Journal, Vol. 25, No. 1, (Winter).

Laurens, J. Bernard, 2005, “Monetary Policy Implementation at Different Stages of Market Development,” IMF Occasional paper No. 244 (Washington: International Monetary Fund).

Ma Delun, 2006, “China's Monetary Policy Transmission Mechanism and Learning from its Development," presentation at a Conference on Monetary Policy Transmission Mechanisms held at the National Bank of the Republic of Belarus, Minsk, Belarus.

Masuch, K., S. Nicoletti-Altimari, H. Pill and M. Rostagno, 2003, "The role of money in monetary policy making," in O. Issing (ed.): Background Studies for the ECB's Evaluation of its Monetary Policy Strategy, chapter 8, pp. 187-228. 
McKinsey Global Institute, 2006, “Putting China’s Capital to Work: The Value of Financial System Reform,” McKinsey Global Institute.

Mehran, Hassanali, Bernard Laurens and Marc Quintyn, 1996, “Interest Rate Liberalization and Money Market Development: Selected Country Experiences,” IMF (Washington:

International Monetary Fund).

Mehran, Hassanali, Marc Quintyn, Tom Nordman and Bernard Laurens, 1996, “Monetary and Exchange Reforms in China: An Experiment in Gradualism,” IMF Occasional Paper No. 141 (Washington: International Monetary Fund).

Mishkin, Frederic S., 2000, “From Monetary Targeting to Inflation Targeting: Lessons from the Industrialized Countries,” in Banco de Mexico, Stabilization and Monetary Policy: The International Experience (Mexico City: Bank of Mexico).

Ning, Su, 2004, “China's economic development and the current macroeconomic policy," Speech at the Conference of Montreal, Canada, June 9, BIS Review 40/2004.

People’s Bank of China, China Monetary Policy Report (various editions)

- 2005, “Report on Advancement of Interest Rate Market Reforms,” People’s Bank of China Monetary Policy Analysis Group (January 2005)

_ 2004, “Challenges to China’s Monetary Policy”, BIS Papers No. 23, pages 124-127, 2004.

Podpiera, Richard, 2006, “Progress in China's Banking Sector Reform: Has Bank Behavior Changed?” IMF Working Paper No. 06/71 (Washington: International Monetary Fund).

Prasad, Eswar, 2004, “China's Growth and Integration into the World Economy: Prospect and Challenges,” IMF Occasional Paper No. 232 (Washington: International Monetary Fund).

Prasad, Eswar, Thomas Rumbaugh, and Qing Wang, 2005, "Putting the Cart Before the Horse? Capital Account Liberalization and Exchange Rate Flexibility in China," IMF Policy Discussion Paper, PDP/05/1 (Washington: International Monetary Fund).

Schaechter, Andrea, 2001, “Implementation of Monetary Policy and the Central Bank's Balance Sheet,” IMF Working Paper No. 01/149 (Washington: International Monetary Fund).

Schaechter, Andrea, Mark R. Stone, and Mark Zelmer, 200, “Adopting Inflation Targeting: Practical Issues for Emerging Market Countries,” IMF Occasional paper No. 202 (Washington: International Monetary Fund). 
Trichet, J.C. (2005), “Asset Price Bubbles and Monetary Policy”, speech prepared for the MAS lecture, Singapore, 8 June.

Walsh, C.E.(2003), Monetary Theory and Policy, The MIT Press, Second Edition, Cambridge, Massachusetts, London.

Wu Xiaoling, 2006, Speech at the Expert Meeting on Analysis and Forecast of 2006 financial situation in China, March 18.

Xiaoling, Wu, 2006, Speech at the Expert Meeting on Analysis and Forecast of 2006 financial situation in China (March 18, 2006).

Xie, Duo, 2002, “Analysis of the Development of China's Money Market”, in China and World Economy, Number 1, 2002.

Xie, Ping, 2004, “China’s Monetary Policy: 1998-2002”, Working Paper No. 217, Stanford Center for International Development.

Xie, Ping and Q. Yuan (2003): “Analysis of the effects of China's interest rate policy in recent years, “ Journal of Financial Research, Beijing, 275: 1-13.

Zhao, Shangmei, "Selection of Intermediate Targets for China's Monetary Policy", Shandong University School of Economics.

Zhou, Xiaochuan, 2005, Exclusive interview with the People’s Daily, March 2005. 2006, "Switch to a New Way of Thinking and Steadily Experiment with Cross-Sector Operation in the Financial Industry," speech at the BoCom-HSBC Forum, June 2006. 